\title{
DoEs WTO MEMBERSHIP MAKE A DIFFERENCE AT THE EXTENSIVE MARGIN OF WORLD TRADE?
}

\author{
GABRIEL FELBERMAYR \\ WILHELM KOHLER
}

CESIFO WORKING PAPER No. 1898

CATEGORY 7: TRAde Policy

JANUARY 2007

An electronic version of the paper may be downloaded

- from the SSRN website:

- from the RePEc website:

- from the CESifo website:

www.SSRN.com

Www.RePEc.org

www.CESifo-group.de 


\title{
DOES WTO MEMBERSHIP MAKE A DIFFERENCE AT THE EXTENSIVE MARGIN OF WORLD TRADE?
}

\begin{abstract}
In his seminal paper, Rose (2004) concluded from a gravity-type study of bilateral trade that the GATT/WTO does not play a strong role in encouraging trade. Rose looks at countries where the amount of trade was positive to start with (intensive margin). In this paper, we present a corner-solutions version of the gravity model of bilateral trade which explains zero trade and leaves room for WTO membership to promote trade at the extensive margin of trade. Relying on a Tobit estimation approach, we find that WTO membership has promoted world trade to a larger extent than Rose's results seem to indicate.
\end{abstract}

JEL Code: F12, F13.

Keywords: gravity approach, WTO, monopolistic competition, real trade costs.

\author{
Gabriel Felbermayr \\ Chair for International Economic Relations \\ University of Tübingen \\ Nauklerstr. 47 \\ 72074 Tübingen \\ Germany \\ gabriel.felbermayr@uni-tuebingen.de
}

\author{
Wilhelm Kohler \\ Chair for International Economic Relations \\ University of Tübingen \\ Nauklerstr. 47 \\ 72074 Tübingen \\ Germany \\ wilhelm.kohler@uni-tuebingen.de
}

December 2006

This paper was partly written while Wilhelm Kohler visited CESifo, Munich, in November 2006. He gratefully acknowledges CESifo's generous hospitality. Special thanks are due to Benjamin Jung for excellent research assistance and to Robert Feenstra and Peter Egger for helpful comments. 


\section{Introduction}

Becoming a member of the WTO is not just a question of "raising one's hand". Accession is subject to a complex negotiation process, which is costly and which involves demands from existing member countries that applicant countries do not necessarily consider to be in their own immediate interest. Perhaps inevitably, bilateral or regional arrangements may often seem more attractive than WTO membership. The accession commitments relate to market access, as well as policy rules not directly related to trade. Both add up to something like a "price" for WTO membership. ${ }^{1}$ Although the price-tag is negotiable, the negotiating process is somewhat lopsided in favor of existing members. Moreover, there is evidence that the price has risen through time; see Evenett \& Primo Braga (2005). Yet, countries are willing to pay this "price", so there must be a benefit. Arguably, the most important and immediate benefit is an expected increase in exports to existing member countries, beyond the levels that would otherwise be reached.

In turn, the "price" that incumbents charge for accepting a new member must be worth something for them as well. Again, it is the expected rise in exports to new member countries. This is in line with what Krugman (1991) has dubbed "GATT think", essentially a two-sided mercantilist obsession with increasing ones exports. However, it is enlightened mercantilism in that the principle of reciprocating market access concessions gives indirect leverage to consumer interests (in cheap imports), which would otherwise be victimized in the domestic political process by dominating producer-interests (in large export market) in both countries. Adding severe restrictions on the use of export subsidies, a further important cornerstone of "GATT think", this enlightened mercantilism unleashes forces towards freer trade. ${ }^{2}$ Under reasonable conditions, but not inevitably, it also leads to more trade.

According to this logic, one would expect that WTO accession boosts bilateral trade

\footnotetext{
${ }^{1}$ In the most recent accession (November 2006), Vietnam's commitments run up to almost 700 pages of text related to slashing trade barriers, ending subsidies, ensuring protection of property rights etc.

${ }^{2}$ More recently, this logic of the GATT/WTO has been formalized by Bagwell \& Staiger (2003). Throughout this paper, we use the term WTO to mean both the WTO and the GATT. All GATT agreements were absorbed by the WTO which came into existence in 1995, based on the Uruguayround agreement under the GATT.
} 
between acceding and existing member countries. In particular, WTO membership is commonly regarded as a key vehicle to integrate less developed countries into the world trading system, and thus to enhance their growth and development perspectives. Did the WTO deliver on this account? This question, of course, has many dimensions, and there is no easy answer. But surely, the GATT/WTO should at least have had a trade-promoting influence. Despite the general perception of the GATT and the WTO as key forces behind the enormous increase in world trade observed after World War II, identifying a statistically significant effect of WTO membership on the volume of bilateral trade turns out to be harder than expected. Several approaches have been pursued in the literature, with varying results. ${ }^{3}$ Perhaps the most important and widely recognized study is Rose (2004a) who searches for a significant effect of WTO membership on the level of bilateral trade in a conventional econometric analysis of a large panel of data covering 50 years and 175 countries, controlling for other determinants as suggested by the gravity theory of trade. Summarizing an extensive investigation exploring many perturbations of the data, Rose concludes, at the time, that "we currently do not have strong empirical evidence that the GATT/WTO has systematically played a strong role in encouraging trade".

Given the aforementioned logic that underlies the GATT, it is not surprising that Rose's findings have caught a great deal of attention. They seem to cast doubt on the GATT/WTO as a "success story" that exemplifies the virtues of multilateral trade liberalization. At a time when countries increasingly seem to turn their back on the multilateral system for the sake of regional trade arrangements, the results must seem like bad news for those who preach the benefits of multilateralism. However, farreaching policy conclusions don't seem warranted. Indeed, it is not even clear whether we have a puzzle. There are several potential explanations for Rose's results, some of them perhaps more worrying than others. Hence, we need more research. In a companion paper, Rose (2004b) has shed further light on the issue by examining whether GATT/WTO member-countries have systematically followed more liberal trade policies than non-members. And his conclusion, again, is that "there is little evidence that membership in the GATT/WTO has actually liberalized trade policy". This seems like a consistent explanation of the results in Rose (2004a), but it also seems to make them more worrying. After all, fostering more liberal trade policies was the GATT's, and still is the WTO's primary mandate. And the presumption underlying the a-priori

\footnotetext{
${ }^{3}$ Brief surveys may be found in Evenett \& Gage (2005) and Rose (2006).
} 
expectation that membership should promote trade is that this mandate has indeed largely been fulfilled.

But the message is not as devastating as may appear at first sight. As Rose (2004b) himself aptly points out, it is important to be aware of a subtle distinction. It may be true that, given the existence of the GATT/WTO, member countries do not pursue systematically more liberal trade policies than non-members. But this does not mean that these policies are less liberal than they would be without the presence of the GATT/WTO as an institution. We probably don't know enough about the counterfactual to reach a firm conclusion on this latter question. In particular, it would certainly be strange to argue, on the basis of Rose (2004b), that the world would be a better place without the GATT/WTO. But still, the "policies-explanation" of Rose (2004a) that Rose (2004b) apparently offers seems to raise a somewhat worrying specter.

However, in this paper we do not want to explore any of the issues related to the "policies-explanation" of Rose (2004a). Instead, we want to go back to the initial results related to trade as such. It must be pointed out that Rose (2004a) has tried out a large number of empirical methodologies on different partitions of his data set in order to reach a robust story. He is careful to point out that the data do tell partial stories where GATT/WTO membership seems to have promoted bilateral trade. But the evidence in his view does not add up to a convincing story of a systematic overall positive influence of membership on trade. ${ }^{4}$

Several authors have since re-addressed the issue, and have come to different conclusions. In his summary of "what happened afterwards", Rose (2006) identifies three dimensions in which his earlier conclusion might need revision. The first relates to "excessive pooling" in the country-, time-, or industry-dimension. In our view, the question here is whether there is enough systematic variation across countries, times, or industries, that would allow us to come up with a helpful and interesting explanation of why GATT/WTO membership fails to exhibit a systematic influence in the full panel. The time-dimension has been explored quite extensively already in Rose (2004a), and the sector-dimension would seem rather obvious, given the "classical" GATTexemptions for sectors like textiles and agriculture. ${ }^{5}$ Exploring the country-dimension,

\footnotetext{
${ }^{4}$ Rose (2005) compares the GATT/WTO with the IMF and the OECD. Following essentially the same strategy as in Rose (2004a), he finds that it is even harder to find such influence of membership in the IMF, whereas OECD-membership does seem to have had a positive effect on bilateral trade.

${ }^{5}$ Rose (2006) surveys other attempts at disentangling specific time and sector effects.
} 
Subramanian and Wei (2006) conclude that GATT/WTO membership promotes trade mainly, and strongly, for industrial countries, but not for developing countries. ${ }^{6}$ Interestingly, their explanation partly runs along the aforementioned "policies-explanation". They argue that industrial countries have simply made more out of their GATT/WTO membership in terms of trade liberalization attempts. A related point is that the GATT/WTO may have served as a trade-liberalizing catalyst also for countries who are not (yet) formal members; see Tomz et al. (2005).

The second potential "revisionist" point relates to whether evidence in the time dimension should deserve more confidence than evidence in the cross-country dimension. In some sense the point is technical in nature, essentially relying on the presumption of unobserved country- (or even dyad-) heterogeneity which makes the OLS panelestimator biased. In terms of substance, an important dimension of unobserved heterogeneity in the usual gravity specification is, of course, trade policy. In the present context, it would seem natural to generalize the trade-costs in the "multilateral resistance" terms of the Anderson \& van Wincoop (2003) gravity equation. These are normally motivated by distance related costs, and used to argue for country-specific fixed effects. They might obviously be generalized to also represent trade policies of the importer- and the exporter-country.

However, in one of his specifications Rose (2004a) did in fact include dyad-specific fixed effects (which nest importer and exporter fixed effects), thus looking only at "within variation" in the time-dimension. And in these specifications, he did find slightly more pro-trade evidence of GATT/WTO membership than in others. But the estimated coefficient was very small, hence this point offers very little comfort. The results obtained by Subramanian \& Wei (2006), who also stress the importance of country-pair fixed effects, thus seem to be due more to the distinction between developed and developing countries than to the more general country-fixed effects. But there is a question of interpretation that arises in this regard. If the GATT/WTO's prime mandate is to foster more liberal trade policy, why should we expect to find any additional trade-promoting influence, once we control for trade policies via fixed effects? To the best of our knowledge, this question has not been addressed so far in the literature. We address it in the model that we propose below.

The third line of criticism acknowledged by Rose (2006) relates to a potential se-

\footnotetext{
${ }^{6}$ Subramanian \& Wei (2006) is a shortened version of their NBER working paper of 2003.
} 
lection bias. By ignoring all country pairs where trade is zero, Rose (2004a) has also ignored a potentially important trade-promoting influence of GATT/WTO membership. Members may trade with more countries than non-members, and a country may experience an increase in the number of trading partners once becoming a member of the GATT/WTO. This is the so called extensive margin of world trade, as opposed to the intensive margin relating to how non-zero trade varies across countries and time. We have argued elsewhere that excluding the extensive margin generates biased estimates, and we have included it via Tobit estimation techniques; see Felbermayr \& Kohler (2006). In one of our specifications we have found evidence of a trade-promoting influence of GATT/WTO membership. ${ }^{7}$ In this paper, we intend to undertake a more comprehensive search for GATT/WTO membership effects at the extensive margin. ${ }^{8}$ Indeed, the concluding words by Rose (2006) in his recent survey set the stage for our analysis. He writes: "I am now persuaded that membership in the GATT/WTO encourages the creation of trading links where none might otherwise exist. How important this is to world trade and welfare is currently unclear to me; I look forward to more work on this area."

More specifically, the plan of our paper is as follows. In section 2, we first present a theoretical model that explains why GATT/WTO membership might play an important role at the extensive margin of world trade. The model is close to Helpman et al. (2006), and it gives rise to what we call a corner solutions approach to the gravity equation. In section 3 , we then show the importance of missing and zero trade data in the Direction of Trade Statistics (DoTS) of the International Monetary Fund (IMF), which we use in our subsequent econometric estimation. Section 4 reports a series of heuristic results on the role of GATT/WTO membership at the extensive margin that we have extracted from our data, without resorting to the gravity equation. In section 5, we turn to an econometric analysis of the gravity equation, based on the corner solutions model of section 2. We first confirm Rose (2004a) in showing that our data (1965-2004) do not reveal a strong and robust effect of WTO membership on the intensive margin of bilateral trade. Subsequently, we put pieces together and

\footnotetext{
${ }^{7}$ Our prime interest in that paper was not GATT/WTO membership, but the so-called "distance puzzle". Evidence of a GATT/WTO effect on the extensive margin was also found by Helpman, Melitz \& Rubinstein (2006) or Liu (2006).

${ }^{8}$ In the remainder of the paper, when using the term WTO, we refer to the entire history of the multilateral trading system (GATT plus WTO).
} 
estimate our corner solutions gravity model. We find the extensive margin to make a difference in two ways. Excluding zero trade observations does, indeed, give rise to a downward-bias of the relevant WTO-coefficient; and WTO membership does promote trade at the extensive margin.

\section{A simple model of the extensive margin}

The standard gravity model of bilateral trade is based on Dixit-Stiglitz-type product differentiation and monopolistic competition, whereby researchers normally assume iceberg-type variable trade costs. These are meant to capture natural barriers to trade, related to distance and transport, as well as policy-induced barriers such as tariffs. The problem with this model is that it does not allow for zero trade between any two countries, hence there is no extensive margin. However, the extensive margin becomes important as soon as there are fixed costs of exporting, and if these costs are specific to the market served. Following Baldwin (1988), we refer to such costs as beachhead costs. ${ }^{9}$ Helpman et al. (2006) show that the combination of beachhead costs and firm level heterogeneity in productivity, combined with cross-country variation in efficiency, implies that any given country need not serve all foreign markets.

This is a natural point of departure to model the WTO at the extensive margin. In particular, we argue that - other things equal - joint WTO membership of the exporter and importer country should lower variable trade costs, as well as the beachhead costs of exporting. For instance, beachhead costs may be due to a certain likelihood that a certain destination country disrupts trade, for instance to alleviate perceived temporary pressure from import competition. Ex ante, an exporting firm may thus face a higher likelihood of periodic temporary reductions in profits from exporting to non-WTO-countries than to a WTO country, provided the exporter country itself is a member. There are several reasons for this, and we do not go into details here. Suffice it to mention the host of rules-related policy commitments entered upon accession (see Evenett \& Primo Braga, 2005), as well as GATT/WTO-type tariff-bindings and

\footnotetext{
${ }^{9}$ Fixed export costs have become important in the recent extension of the monopolistic competition model to heterogenous firms; see Melitz (2003) and Helpman et al. (2006). There are other ways to model the extensive margin, but the beachhead cost model proves convenient for the present purpose. In Felbermayr \& Kohler (2006), we have proposed an argument based on public infrastructure investment, rather than private costs of exporting.
} 
the reduction of uncertainty afforded by the WTO rules on safeguard-protection, antidumping-provisions, and trade related intellectual property rights (or property rights more generally). In an intertemporal model, GATT/WTO membership would thus affect the present value of future profits from exporting. Here, we take a short-cut and model this as lower beachhead costs in a static monopolistic competition model of exporting.

Suppose the world consists of $C$ countries, $i=1, \ldots, C$, which differ only with respect to their aggregate efficiency, which we denote by $\left(c^{i}\right)^{-1}$. For simplicity, assume that labor is the only factor of production, and firms produce different varieties of a single good, whereby all consumers have identical Dixit-Stiglitz-type CES preferences, with $\sigma \equiv 1 /(1-\rho)>1$ describing the elasticity of substitution between any two (symmetric) varieties. Firms have constant, but different marginal labor input requirements per unit of output, denoted by $a$. We assume that $a$ is distributed according to some cumulative distribution function $G(a)$, which is identical across countries and has support $\left[a_{L}, a_{H}\right]$. Notice that the variable $a$ relates to the firm's distinct own variety. We simplify by using a to also index producers and, thus, varieties according to the Dixit-Stiglitz utility function. Since $G(a)$ is identical across countries, we abstain from additionally indexing $a$ by the producer-country.

For the sake of simplicity, we abstain from determining entry and exit of firms as such. We assume a given number of $N^{i}$ firms in country $i$, all of which are actively selling on their home market. We refer to Melitz (2003) for a mechanism determining the continuous analogue to our $N^{i}$. In this mechanism, $N^{i}$ would be influenced by the prospect of exporting through an aggregate zero-profit condition, including profits on exporting. Our partial equilibrium model thus squarely focuses on the extensive margin of exporting. ${ }^{10}$ In our exposition, we closely follow Helpman (2006).

Denoting the c.i.f.-price for a good of variety $k$ in country $j$ by $p_{k}^{j}$, demand for this variety may be written as $x_{k}^{j}=A^{j}\left(p_{k}^{j}\right)^{-\sigma}$, where $A^{j} \equiv Y^{j}\left(P^{j}\right)^{\sigma-1}$. In this expression,

\footnotetext{
${ }^{10} \mathrm{It}$ is worth pointing out at this stage that it is beachhead costs, not firm-level heterogeneity, that give rise to the extensive margin of trade on the country-level, separating positive-trade from zerotrade partner countries. Firm-level heterogeneity introduces an extensive margin of exporting within each country, where firms engaged in serving a specific foreign market are separated from those who don't. While not necessary for the extensive country-margin, assuming firm-level heterogeneity adds some realism to our model, and it facilitates an easier interpretation against the backdrop of existing literature.
} 
$Y^{j}$ is equal to country $j$ 's expenditure on goods, and $P^{j}$ is the unit-expenditure function (or exact price index), depending on prices of all varieties served to market $j .^{11}$ Since each producer manufactures a unique variety, she has market power. Following established tradition, we assume that each producer in country $i$ treats $P^{j}(i=1, \ldots, C)$ as given, thus perceiving a price elasticity of demand equal to $\sigma$. Normalizing the wage to unity, marginal costs of a producer $a$ are equal to $c^{i} a$, and her profit-maximizing "ex-factory" price is equal to $c^{i} a / \rho$, where $1 / \rho>1$ is the usual markup factor.

Firms in country $i$ who consider to serve consumers in country $j$ must incur fixed beachhead costs equal to $c^{i} f^{i j}$, depending on the identity of the exporter $(i)$ and the importer $(j)$ country. ${ }^{12}$ Notice that these costs also depend on the exporter country's aggregate efficiency parameter $c^{i}$. Besides the beachhead costs, there are variable trade costs of the usual iceberg type, denoted by $\tau^{i j} \geq 1$. Domestic sales do not require any of these costs, whence $\tau^{i j}=1$ and $f^{j j}=0$. The profit-maximizing c.i.f.-price in country $j$ is then equal to $c^{i} a \tau^{i j} / \rho$.

By assumption, all firms are active on their domestic markets where there are no trade costs. Additional profits to be earned by exporting from country $i$ to country $j$ depend on a firm's efficiency and are given by

$$
\pi^{i j}(a)=B^{j}\left(c^{i} \tau^{i j} a\right)^{1-\sigma}-c^{i} f^{i j}
$$

where $B^{j} \equiv A^{j}(1-\rho) \rho^{\sigma-1}$. Note that from a single firm's perspective $B^{j}$ is given, hence profits are linear in $\left(c^{i} \tau^{i j} a\right)^{1-\sigma}$, whereby $B^{j}$ is a measure of the size of the foreign market $j$. The marginal firm which just breaks even on exports to foreign market $j$ is determined by the condition $\pi^{i j}(a)=0$. This gives rise to a cut-off value

$$
a^{i j}=\left[\frac{B^{j}}{\left(c^{i}\right)^{\sigma} f^{i j}}\right]^{\frac{1}{\sigma-1}} / \tau^{i j},
$$

such that all firms with efficiency $a>a^{i j}$ would make losses by exporting from country $i$ to country $j$. Clearly, this cut-off value is specific to the exporter-importer-relationship,

\footnotetext{
${ }^{11}$ Due to firm-level heterogeneity, this price index depends on the cumulative density function $G(a)$ and is, therefore, considerably more complex than the standard formulation.

${ }^{12}$ Notice that in a multi-factor world cross-country variation in $c^{i}$ would also be determined by the interaction of international factor price differences and the factor intensity of the beachhead effort. In this way, $c^{i}$ could vary across countries even with identical technology. The same applies for marginal costs of production $c^{i} a$, where the factor intensity of beachhead and production activity could be allowed to differ. Variations in $c^{i}$ thus allow for both, a Ricardian a Heckscher-Ohlin interpretation.
} 
and it is increasing in the size of the foreign market $B^{j}$. It also increases in the exporting country $i$ 's overall efficiency $1 / c^{i}$, while falling with higher beachhead costs $f^{i j}$, and higher variable trade costs $\tau^{i j}$. All of this is intuitive.

A country- $i$-firm with $a<a^{i j}$ will have export sales to country $j$ equal to $\left(c^{i} a \tau^{i j} / \rho\right) \times$ $A^{j}\left(c^{i} a \tau^{i j} / \rho\right)^{-\sigma}=A^{j} \rho^{\sigma-1}\left(c^{i} a \tau^{i j}\right)^{1-\sigma}$. We now define a latent variable

$$
\Lambda^{i j}=A^{j} \rho^{\sigma-1}\left(c^{i} \tau^{i j}\right)^{1-\sigma} N^{i} \int_{a_{L}}^{a^{i j}} a^{1-\sigma} \mathrm{d} G(a) .
$$

In this expression, the integral is the "Melitz-aggregator" which allows us to describe aggregate exports in the face of firm-level heterogeneity, given $N^{i}$, the exogenous number of producing firms in country $i$. Notice, however, that $\Lambda^{i j}$ is positive only if $a^{i j}>a_{L}$. It is zero if $a^{i j}=a_{L}$, and negative if $a^{i j}<a_{L}$. Hence, the expected value of exports from country $i$ to country $j$ obeys ${ }^{13}$

$$
X^{i j}=\left\{\begin{array}{ll}
\Lambda^{i j} & \text { if } \Lambda^{i j} \geq 0 \\
0 & \text { if } \Lambda^{i j}<0
\end{array} .\right.
$$

With a constant elasticity of substitution, export revenues and profits are driven by the same variables, except for beachhead costs which matter only for profits. Since we normally cannot measure beachhead costs, expression (4) can be understood as a corner solution model; see Felbermayr \& Kohler (2006).

It is convenient to define a function $\Gamma^{i j}\left(a^{i j}\right) \equiv \int_{a_{L}}^{a^{i j}} a^{1-\sigma} \mathrm{d} G(a)$. We now assume this function to be of the same shape for all country-pairs, and we venture the bold assumption of a log-linear form, so that $\ln \Gamma^{i j}\left(a^{i j}\right) \approx \Gamma_{0}+\gamma \ln a^{i j}$. Using (2), we then have

$$
\ln \Gamma^{i j}=\Gamma_{0}+\gamma\left(\frac{\sigma}{1-\sigma} \ln c^{i}+\frac{1}{1-\sigma} \ln f^{i j}-\ln \tau^{i j}\right) .
$$

Inserting into the expression of our latent variable $\Lambda^{i j}$, we obtain

$$
\ln \Lambda^{i j}=\Lambda_{0}^{i j}+\left(1-\sigma+\gamma \frac{\sigma}{1-\sigma}\right) \ln c^{i}+(1-\sigma-\gamma) \ln \tau^{i j}+\gamma \frac{1}{1-\sigma} \ln f^{i j},
$$

where $\Lambda_{0}^{i j} \equiv \Gamma_{0}+\ln \left(\rho^{\sigma-1} A^{j} N^{i}\right)$. Notice that $\sigma>1$ by assumption.

Figure 1 illustrates the corner-solutions nature of this extensive-margin-model. It depicts $\ln \Lambda^{i j}$ as a linear function of $\ln \tau^{i j}$, plotting $-\ln \tau^{i j}$ towards the left. The dashed parts of the lines $\ln \Lambda^{i j}$ indicate the corner solution in line with (4). The

\footnotetext{
${ }^{13}$ Obviously, in this model negative exports may not be interpreted as imports.
} 
underlying assumption is that country $j$ is a WTO member. A "within-variation" at the intensive margin can now be depicted as $\Delta \ln \Lambda^{i j}=(1-\sigma-\gamma)\left(\ln \tau_{1}^{i j}-\ln \tau_{0}^{i j}\right)+$ $[\gamma /(1-\sigma)]\left(\ln f_{1}^{i j}-\ln f_{0}^{i j}\right)$, whereby the variable and beachhead cost values marked 1 (0) indicate a situation where country $i$ has (not yet) become a member of the WTO. A "within-variation" at the extensive margin would be observed for some other country $l$, starting out from a higher value of real trade $\operatorname{costs} \tau_{0}^{l j}$, where the same beachheadcost-reduction from country $j$ joining the WTO alone would suffice to "wake up" a dormant trading relationship. A "between-variation" at the extensive margin would be observed between countries $k$ and $l$, both having the same level of real trade costs $\tau_{0}^{k j}=\tau_{0}^{l j}$, but with country $k$ being a member of the GATT/WTO while country $l$ is not. It is obvious that any such "between-variation" could also be caused by differences in overall efficiencies $c^{k}$ and $c^{l}$.

We shall use this corner-solutions model of bilateral exports, in order to specify a gravity equation which we then estimate on a panel data set comparable to Rose (2004a). Details on that specification, as well as the estimation strategy will follow below. What we want to do next is provide some descriptive evidence on the importance of the extensive margin in post-war evolution of world trade, and to investigate by means of simple heuristic techniques whether GATT/WTO membership appears to play a role at the extensive margin.

\section{Quantifying the extensive margin of trade}

To discuss the empirical importance of the extensive margin of world trade, we rely on the IMF Direction of Trade Statistics (DoTS) which is a commonly used collection of yearly export and import data of manufactured goods for a large number of countries. According to the CIA fact-book, due to de-colonialization and the breakup of the Soviet Union and other smaller countries, the number of sovereign countries has increased from 67 in 1945 to 192 in 2005 . While the entry of new countries into the panel per se is not a problem in the econometric analysis, it potentially blurs the descriptive analysis that we are about to undertake now. ${ }^{14}$ In the descriptive analysis of this section, we

\footnotetext{
${ }^{14}$ Whenever new countries are formed, measured world trade increases, simply because trade flows that were formerly classified as internal become external trade. Following Felbermayr \& Kohler (2006), we refer to growth of world trade due to the increase in the number of countries as to the pseudo-extensive margin.
} 
therefore focus on a balanced panel of countries by restricting ourselves to a sample of 104 countries that have consistently been sovereign from 1965 right up to 2004 . This sample contains industrialized countries, as well as developing countries and a couple of formerly communist countries (such as China or Poland). ${ }^{15}$ According to the DoTS, roughly $89 \%$ of the 2004 total value of world trade (approximately 841 billion US dollar) is attributable to country pairs that have existed before 1965, and $11 \%$ to pairs created after 1965 .

We define a trading relationship either as a directed dyad (exports from $i$ to $j$ ) or as undirected dyads (exports in both directions, i.e., from $i$ to $j$ plus $j$ to $i$ ). In the following, we also call an undirected dyad a bilateral trading relationship. In the first case we have $104 \times 103=10,712$ country pairs per year, while in the second we have half that number, i.e., 5, 356. Figure 3.1 plots the fraction of directed relationships for which exports where either positive, zero, or missing. Clearly, the number of export relationships has increased quite substantially from 1966 to 2004. While in 1966 a mere 37 percent of all potential trading relationships were active, this number has gone up to about 80 percent by 2004 . In contrast, during the same time span the share of relationships characterized by missing trade has fallen from about 16 percent to 2 percent, with a major improvement in the data coverage occurring around 1981. Over the forty years from 1965 to 2004, 7.6 percent of all directed dyads feature missing trade, 35.4 percent have zero trade, and the remaining 57 percent have strictly positive trade volumes.

Figure 3.2 decomposes bilateral trading relationships. A bilateral trading relationship is considered active if at least one partner has positive exports. More precisely, let $I_{i j t}=1$ if $X_{i j t}>0$ and zero otherwise, and then define $S_{i j t} \equiv I_{i j t}+I_{j i t}$. Obviously, $S_{i i j t}$ is zero if there is no trade between countries $i$ and $j$ at time $t$. It takes the value of 1 if either $i$ has positive exports to $j$ or $j$ has positive exports to $i$. Finally, becomes 2 if both countries have positive exports to each other. In figure 3.2 we plot the fraction of bilateral trading relationships where $I_{i j t}=2$ (two-way trade), $I_{i j t}=1$ (one-way trade), $I_{i j t}=0$ (zero bilateral trade). Missing refers to the case where $X_{i j t}$ and $X_{j i t}$ are both missing.

Figure 3.3 gives a rough sense of magnitude regarding the importance of the extensive margin by depicting the cumulative share of trading relationships with different

\footnotetext{
${ }^{15} \mathrm{~A}$ complete list of countries is available upon request.
} 
"vintage". For instance, the figure shows that the 1965- "vintage" of trading relationships (those that had strictly positive trade already in 1965) is responsible for about 85 percent of the 2004 trade volume. In other words, the total contribution of the extensive margin to 2004 trade over the time span 1965 to 2004 is about 15 percent. Clearly, as we move towards more recent "vintages", the cumulative contribution of the extensive margin becomes smaller and smaller. ${ }^{16}$ Overall, figures 3.1 through 3.3 clearly suggest that the extensive margin has played a non-negligible role for the total growth of world trade from 1966 up to 2004.

\section{WTO membership at the extensive margin: heuris- tic evidence}

In this section, we first explore "heuristic evidence" on WTO membership at the extensive margin of world trade that may be extracted without relying on a fully specified corner-solutions gravity-model of trade. We first take a cross-sectional perspective, and then turn to the time-series dimension. Table 4.1 runs a multinomial Logit model of the variable $S_{i j t}$ (defined above) on the two dummies BOTHIN and ONEIN, alongside common-sense covariates, such as GDPs of both countries, geographical distance, adjacency, common language, and a comprehensive set of time dummies. We take the zero-trade outcome of $S_{i j t}$ as the benchmark and show coefficients transformed into marginal effects at the respective covariate sample means. The results are in line with expectations. If two countries are simultaneously in the GATT/WTO, the probability for $S_{i j t}=2$ is about 15 percentage points higher than the one for $S_{i j t}=0$. The other covariates similarly take values according to intuition. All coefficients are different from zero at conventional levels of statistical significance.

Do WTO members systematically have more active trading relationships? Limiting attention to 110 countries that have been existing since 1965, we find that the average number of trading partners has increased from 42 in 1965 to 86 in 2004. Given the overall number of members at any point in time, the model proposed above would predict that - ceteris paribus - member countries should have more active trading

\footnotetext{
${ }^{16}$ In figure 3.3, whenever a trading relationship featuring missing trade turns positive, this is recorded as a movement on the extensive margin. This may be misleading, as missing trade need not imply zero trade. It may also explain the blip in the year of 1978.
} 
relationships than non-members. As a rough first check, we run a simple Poisson regression with fixed effects, explaining the number of trading partners of a country as a function of its own WTO membership and various country characteristics. We also include a set of time dummies to capture common time trends. Table 4.2 sets the Poisson results against a linear model, which we estimate with OLS, and a negative binomial model augmented by fixed effects. The results support our expectation. The linear model predicts that joining the WTO increases the expected number of trading partners by 4.3. The Poisson model implies that WTO members have 12 percent more trading partners than non-members, while the negative binomial model shows a smaller effect of about 9 percent. ${ }^{17}$ Given that the sample mean of the number of trading partners is 57, the non-linear results imply that WTO members have between 5.1 and 6.8 more trading partners than non-members. Note that these results are robust to omitted variables bias to the extent that those are time-invariant.

Countries with more trading relationships need not necessarily have a more diversified trade pattern. We have argued above that trade with a fellow WTO member country involves a lower risk of unexpected policy interference or enforcement problems. We have crudely modelled this through country-pair-specific beachhead costs. However, depending on the underlying correlation structure, firms might also be able to deal with this type of risk through diversifying their export destinations. As a result, WTO members would feel less pressure to diversify their trade structure and would converge to a less diversified structure of trade which is more in line with the pattern of comparative advantage. At the same time, if WTO membership goes hand in hand with decreased trade costs, new trading partners may become attractive destinations, thus leading to a lower degree of concentration. A priori, the effect would seem ambiguous. To obtain a first rough idea on which of the two effects was dominant in post-war development of trade, we compute the Herfindahl index of export concentration. ${ }^{18}$ Figure 4.1 suggests that WTO membership is indeed associated with lower levels of export concentration.

We run a simple linear regression model to check whether the pattern depicted in figure 4.1 survives conditioning on covariates, such as the country's GDP, its remoteness

\footnotetext{
${ }^{17}$ On the differential interpretation of exponential and negative binomial models, see Wooldridge (2002, p. 646-653).

${ }^{18}$ The Herfindahl index for country $i$ is defined as $\sum_{j} X_{i j}^{2} /\left(\sum_{j} X_{i j}\right)^{2}$.
} 
(measured by average distance of country $i$ from its trading partners), total GDP of the world economy, and the total number of WTO members. Table 4.3 reveals that WTO membership is associated with a lower degree of concentration. But, though statistically significant and robust, the effect is rather small. WTO members have a concentration measure which is between 0.012 and 0.015 points lower than that of non-members. Given that the average degree of concentration is 0.20 , the conclusion is that WTO membership does not make a large difference across countries for the destination-country-concentration of exports.

Finally, we turn to the time series dimension, asking whether WTO membership comes with a higher likelihood for a dormant trading relationship to rise into activity. Figure 4.2 plots average yearly transition probabilities for WTO members (right-hand panel labelled 1) and non-members (left-hand panel labelled 0), again looking only at countries that have existed as sovereign entities throughout the entire period from 1965 to 2004. As a general pattern, the probability that a given zero turns into a positive trade flow (marked $\operatorname{Pr}(\geq 1)$, lighter shade) has risen through time for both, member countries and non-members. However, in all periods of time WTO members have consistently turned zero trade flows into positive ones with slightly higher probabilities. The opposite pattern obtains when looking at the transition from positive trade flows into zeros (marked $\operatorname{Pr}(\leq 1)$, darker shade). The associated probabilities are always lower than the probabilities to transit from inactivity to activity, and lower for GATT/WTO members than for non-members. However, while the probability has remained fairly stable for the group of members (right-hand panel), it has fallen for the group of non-members.

\section{WTO membership: an econometric analysis}

The heuristic evidence of the preceding section seems to indicate that GATT/WTO membership matters at the extensive margin of trade creation. However, while we did include some covariates here and there, we certainly did not control for other determinants of trade in any systematic way. It is worth remembering that Rose (2004a) was able to estimate a highly significant positive effect of GATT/WTO membership ceteris non paribus, i.e., leaving other factors uncontrolled for in the procedure. The point was that the effect has all but vanished, once standard gravity effects have been allowed to enter the stage. Of course, there are several ways to bring structural determinants 
of trade into the picture, and any single approach is unlikely to capture them all. But arguably, the gravity approach is the most convincing one in this context, for at least two reasons. First, unlike the traditional theory of comparative advantage, it is able to explain not only a country's global trade, but also its bilateral trade. And secondly, it has been remarkably successful empirically, consistently throughout several decades of applied research.

However, although we have alluded to the gravity approach in section 2 above, equation (6) is not yet a gravity equation, ready for estimation. The variables $c^{i}$, $\tau^{i j}$ and $f^{i j}$ will all be replaced by appropriate proxy variables. This is essentially a question of data availability and efficiency of estimation; see below. On a conceptual level, we need to close the model in two different ways. First, for the exporter country $i$, we must impose a factor market clearing condition which gets rid of $N^{i}$ for the sake of country $i$ 's GDP and the price and output of its variety. And secondly, we need to solve for $P^{j}$ the overall price index for the destination country, which is a complex function of all c.i.f. prices. This introduces a comprehensive interdependency across all exporter countries' values for $c^{i}, \tau^{i j}$ and $f^{i j}(i=1, \ldots, C)$. We refer to Feenstra (2004) for a convenient summary of how an estimable gravity equation might be derived. The specification that we eventually employ may be written as

$$
\begin{aligned}
\ln \Lambda^{i j}= & \beta_{1} \mathrm{BOTHIN}^{i j}+\beta_{1} \mathrm{ONEIN}^{i j}+\beta_{3} \ln \mathrm{FTA}^{i j}+\beta_{4} \ln \mathrm{DIST}^{i j} \\
& +\beta_{5} \ln \mathrm{ADJA}^{i j}+\beta_{6} \mathrm{LANG}^{i j}+\nu+\nu^{i}+\nu^{j}+u^{i j}
\end{aligned}
$$

where $\nu$ is a constant, $\nu^{i}$ and $\nu^{j}$ are exporter and importer fixed effects, and $u^{i j}$ is an error term with the conventional properties. The other variables on the right are selfexplanatory dummies, with BOTHIN ${ }^{i j}$ and ONEIN $^{i j}$ indicating GATT/WTO membership and $\mathrm{FTA}^{i j}$ indicating joint membership in a regional trading block. With the existence of a time dimension, we need to include time-varying fixed effects $\nu^{i} \times \nu^{t}$ and $\nu^{j} \times v^{t}$, as argued by Baltagi, Egger \& Pfaffermayr (2003) and Baier \& Bergstrand (2006). This is common practice in lieu of a more satisfactory treatment of "multilateral resistance" that Anderson \& van Wincoop (2003) have shown to be a key determinant of bilateral trade in the gravity equation. Inclusion of time-varying fixed effects takes into account all exporter- or importer-specific determinants of trade, such as in particular the two country's GDP. ${ }^{19}$ In this way, all terms appearing in $\Lambda_{0}^{i j}$ in equation (6) are eventually covered by fixed effects, while the forces behind $c^{i}, \tau^{i j}$ and

\footnotetext{
${ }^{19}$ We alternatively use GDP and time-varying country-specific effects in our estimations.
} 
$f^{i j}$ are taken up by the usual resistance dummies of the gravity equation (joint FTA membership, geographical distance, adjacency, and common language), amended by the WTO dummy which is the prime focus of our analysis.

Equation (7) is not ready for estimation, since it involves latent trade as a dependent variable. Adding (4) generates a corner-solutions model of bilateral trade. Applying the logic developed in Wooldridge (2002, p. 524-5), we demonstrate in Felbermayr and Kohler (2006) that any empirical specification where the zero trade observations (and thus corner solutions) are ignored implies an omitted variable bias, leading to inconsistent estimates of all variables in the model. In particular, an empirical strategy that draws on non-zero trade data only, as in Rose (2004a), will systematically underestimate the effect of WTO membership on trade. Importantly, even if the extensive margin as such does not contribute a lot to the growth of world trade, as some of the figures above might suggest, this does not imply that it is irrelevant for estimation: Estimates based on non-zero trade flows alone, i.e., the intensive margin estimates, will be biased downward nonetheless.

In line with the arguments in Felbermayr \& Kohler (2006), we estimate our cornersolutions model employing a Tobit estimation approach. This allows us to disentangle the two margins, which seems important also with respect to the influence of GATT/WTO membership on world trade. In particular, writing $Z_{t}^{i j}$ for the entire explanatory variables, the expected value of bilateral exports, conditional on $X_{t}^{i j}$ can be decomposed according to

$$
E\left(X_{t}^{i j} \mid Z_{t}^{i j}\right)=E\left(X_{t}^{i j} \mid Z_{t}^{i j}, X_{t}^{i j}>0\right) \times \operatorname{Pr}\left(X_{t}^{i j}>0 \mid Z_{t}^{i j}\right) .
$$

Tobit estimation allows us to present separate marginal coefficients for both terms on the right-hand side, the first being the traditional intensive margin, the second being the extensive margin. In the subsequent presentation of results, we report marginal effects on $\operatorname{Pr}\left(X_{t}^{i j}>0 \mid Z_{t}^{i j}\right)$ from Probit estimation, and marginal effects on $E\left(X_{t}^{i j} \mid Z_{t}^{i j}\right)$ from Tobit estimation.

Introducing trading arrangements as explanatory variables in (7) raises an endogeneity issue, as emphasized by Baier and Bergstrand (2006). They argue that countries might select endogenously into free trade agreements. Specifically, if countries select into FTAs because they hope for deeper integration, FTA membership is negatively correlated with the current level of trade (and hence the error term), as higher current inefficiencies make FTA membership that more attractive. In that case conventional estimates of FTA effects are biased downward. However, that logic is not entirely 
compelling for the case of WTO membership, because it could go the other way round as well: A country that receives some positive exogenous shock trades more than the natural level indicated by the gravity equation. That additional trade may make it more valuable to join the WTO, since transparency and predictability of partners' trade policy may now be more valuable. Moreover, the recipe proposed by Baier \& Bergstrand (2006) in order to counter the omitted variables problem, namely the use of dyadic fixed effects, appears questionable for the WTO context, for the simple reason that the WTO is a multilateral, not a bilateral system. We follow common practice in using time-varying fixed effects to capture multilateral trade resistance; see Anderson \& van Wincoop (2003) and Feenstra (2004). This also takes care of the unobserved heterogeneity on the country level that may affect the decision to join the WTO (such as positive shocks discussed above).

A few words on the data, before we proceed to the estimation results. We have clipped the data to the extent necessary in order to obtain a balanced panel. We use the exporter country GDP-deflator to compute real trade flows. Real GDP values are taken from the World Development Indicators. Data on geographical distance, adjacency, and common language are from CEPII, Paris. The FTA dummy was constructed following Baier and Bergstrand (2006). The appendix provides the usual summary statistics for data.

Throughout all our specifications, we use bilateral exports as the dependent variable. Note that the inclusion of fixed effects renders GDP-variables as covariates redundant. We have pursued the following estimation strategy. The first stage of our strategy involves looking only at "between-evidence" in cross country estimations for several sample years with 10-year-intervals. The second stage then moves on to panel estimates, thus adding the "within-perspective". In both stages, we first look at simple OLS estimates from country-pairs with positive trade (intensive margin), mainly for the purpose of comparison with existing literature, in particular Rose (2004a). Subsequently, we undertake a Probit estimation for the extensive margin in isolation, and in a final step we complete each of the two stages with a joint treatment of the extensive and intensive margin via Tobit estimation. Table 5.1 presents the cross section results, while table 5.2 contains panel estimates. In the following discussion we mainly focus on the effect of GATT/WTO membership.

Table 5.1 shows our results from stage one, starting in the top panel with evidence drawn from the intensive margin alone. The estimates of the distance, adjacency 
and common language coefficients, as well as their behavior over time, are closely in line with existing literature. Our data which extend to very recent periods and feature a specific sample of countries (balanced panel) thus yield conventional results, if treated conventionally. ${ }^{20}$ Turning to GATT/WTO membership, we see that the crosssectional variation does not yield robust, meaningful estimates. The point estimates for the coefficient on BOTHIN ${ }^{i j}$ (unity if both countries are WTO members, and zero otherwise), vary between 0.604 and -3.655 . They are mostly negative and statistically insignificant. This mirrors the finding of Rose (2004a). The middle panel reports findings from a Probit model of the extensive margin, using the same covariates as in the upper panel. The same message transpires regarding GATT/WTO membership: The estimates lack robustness and stability over time, with the single exception of year 1995. WTO membership does not appear to be associated with a higher likelihood that a potential trading relationship is operative.

Finally, the bottom panel of table 5.1 displays results for the cross-section Tobit estimation of our corner-solutions model. We transform the dependent variable to $\ln \left(X_{t}^{i j}+1\right)$, which allows us to continue with a log-log gravity model. ${ }^{21}$ Except for the WTO membership variables, the corner-solutions model performs as expected: Relative to the upper panel, where only non-zero trade observations were used and coefficient estimates are biased towards zero, all coefficients in the Tobit case are larger in absolute terms, thus confirming the attenuation bias from the omitted variable misspecification. As to the WTO membership effects, we continue to find estimates that are unstable quantitatively, and mostly insignificant statistically. The conclusion from the cross sectional evidence is that there is no evidence for a positive and sizeable WTO effect on bilateral trade. In other words, moving from the non-zero trade flow model of Rose (2004a) to our corner-solutions model does not help. Estimates are somewhat larger, but nonetheless statistically insignificant and economically meaningless.

From the previous work briefly surveyed in our introduction, it consistently tran-

\footnotetext{
${ }^{20}$ For instance, compare our findings to Baier and Bergstrand (2006), table 1.

${ }^{21}$ This is, admittedly, inelegant. However, semilog gravity models tend to perform very poorly. In Felbermayr and Kohler (2006) we argue that adding constants other than unity to bilateral trade values does not substantially alter the results. The simple approach of adding one makes the Tobit model comparable to the conventional non-zero gravity model, an advantage that would be lost if nonlinear methods were used. Liu (2006) follows Santos Silva and Tenreyro (2006) and runs a Poisson model to account for the extensive margin in a gravity model.
} 
spires that drawing on time-series variation makes finding robust and meaningful WTO membership effects somewhat easier. ${ }^{22}$ To see if this hold in our case as well, we move to stage two of our strategy, exploiting the time-series ("within") dimension of the data, jointly with the cross-sectional ("between") variation. As regards WTO membership, we face the difficulty of appropriately timing the start of the "treatment effect". Countries might undertake steps towards trade liberalization in the run-up towards joining the WTO, and they could be allowed considerable transition periods after joining. ${ }^{23}$ To avoid these complications, instead of using 40 years of data (from 1965 to 2004), we use only five years $(1965,1975,1985,1995$, and 2004).

Table 5.2 reports our findings for stage two of our estimation strategy, i.e., panel regressions. As argued above, consistent estimation of the gravity equation requires inclusion of time-varying fixed effects, in addition to a rigorous treatment of the extensive margin. ${ }^{24}$ We organize our presentation around the inclusion/exclusion of fixed effects (FE). The first three columns exclude all country-fixed effects, which corresponds to the baseline method used by Rose (2004a). Columns (4) through (6) include timeinvariant fixed effects as in Felbermayr and Kohler (2006), and finally, columns (7) through (9) relate to a model including time-varying country-fixed effects. ${ }^{25}$ This is consistent with the theoretical requirements of the Anderson \& van Wincoop (2003) gravity model estimated with time-varying data.

Over all specifications, the behavior of estimates other than those for WTO membership are largely in line with the literature. Column (1) is a variant of Rose's (2004a) base model, restricted to positive trade flows (intensive margin only) and estimated

\footnotetext{
${ }^{22}$ For a more detailed survey, see Rose (2006).

${ }^{23}$ It is not uncommon to observe a 10 year time span for accession negotiations; see Evenett \& Primo Braga (2005). It seems plausible to assume that some policy changes are enacted beforehand, in order to solve the inherent commitment problem. At the same time, it is well known that new members are sometimes slow in honoring commitments entered during negotiation, China being a prominent example in this regard.

${ }^{24}$ In the descriptive analysis, we carefully avoid the pseudo-intensive margin and focus on a balanced panel of country pairs that have existed from 1965 onwards. In the econometric exercise, for reasons of comparison, we stick to the same sample of countries. The panel is (potentially) unbalanced, because for some pairs trade is missing. Availability of GDP data is not an issue whenever we use time-varying fixed effects.

${ }^{25}$ Fixed effects always means a dummy for country $i$ as an exporter and a dummy for country $j$ as an importer, and not dyad-specific dummies.
} 
over 5 years of data rather than over 50 years. We also use a somewhat shorter list of covariates, and - perhaps most importantly - use directed exports, rather than total bilateral trade as a dependent variable. Rose's main finding are upheld: There is no effect of WTO membership on trade. However, looking at the extensive margin with a Probit model, as in column (2), we do find a positive effect, and the same holds for the Tobit model in column (3). The Probit effect is fairly small, implying that WTO membership increases the likelihood of positive trade by 1.1-fold, a mere 10 percent. However, the Tobit estimate is large: WTO membership increases exports from one member to the other by 2.5 -fold: $e^{0.941}=2.56$, or a $156 \%$ increase.

In line with Felbermayr \& Kohler (2006), columns (4) to (6) include time-invariant fixed effects for exporter countries $i$ and importer countries $j$. Focusing on strictly positive trade flows, we find no evidence for an effect of WTO membership, and the same holds for the Probit model. But the Tobit model does signal some positive influence of WTO membership which is significant: Joint membership leads to an increase in bilateral export by about 24 percent $\left(e^{0.212}=1.24\right)$.

The specification in columns (7) to (9) is fully consistent with theory and yields consistent estimates for membership effects. Interestingly, we now find a positive membership effect also in the conventional, positive-trade-only regression. The order of magnitude - a 19 percent increase - is similar to that found in frameworks with time-invariant fixed effects in Rose (2004a). The Probit estimate reveals a significant effect also at the extensive margin, albeit very small in magnitude. Finally, the corner-solutions model implies that joint WTO membership boosts bilateral exports on average by 31 percent $\left(e^{0.267}=1.31\right)$.

It is interesting to look at the ONEIN-effects, although there seems to be a less clear cut theoretical prediction for these than for the BOTHIN-effects. Yet, there is a relatively clear picture that emerges from table 5.2. ONEIN-coefficients tend to be significant in the same specifications where BOTHIN is significant. Moreover, where significant at all, the ONEIN-coefficients are both, larger and have lower standard errors of estimate than the BOTHIN-estimates, the sole exception being the OLS-intensivemargin with time-varying fixed effects in column (7). 


\section{Conclusion}

Having allowed for the extensive margin of world trade to "speak out", can we be confident that WTO membership is worth its "price", more than Rose's (2004a) initial work seemed to suggest? Can we conclude that "GATT think" has, after all, been working during adult phases of the GATT/WTO's life? Working in the sense that countries did reveal more trade, once becoming members, and more trade than countries outside the GATT/WTO? Or does controlling for gravity determinants of bilateral trade continue to destroy all evidence that would support the commonly held view that membership is trade promoting, even if we allow membership to play a role also at the extensive margin of world trade?

In our view the answer is a "qualified yes". Yes, because Probit and Tobit estimations did indeed yield more, and more significantly positive coefficient estimates for our BOTHIN-dummies. And the order or magnitude revealed is not negligibly small. But qualified, because the Probit and Tobit estimates are smaller and less significant in the specification with time-varying country-fixed-effects, which is the preferred specification on theoretical grounds unrelated to WTO membership. More generally, one would have wished the effects to be more robust across different fixed-effects-specifications, or to show up more in the preferred specification than vice versa. Qualified also because the ONEIN-effect which seems much less clear theoretically comes out more significantly than the BOTHIN-effect that we have argued in our own theoretical reasoning. And qualified also because the evidence in favor of a WTO membership effect seems mainly concentrated in the "within-variation". But although one might have wished the evidence to show up more consistently in both dimensions, here one can argue to be on the safe side, since there are fundamental theoretical reasons that we have indicated in the introduction for "within-evidence" to be more trustworthy than "between-evidence".

Abstaining from jargon, what is the message that we have for negotiators and policy makers? It would be silly trying to distill a sharp conclusion regarding practical problems in accession negotiations and decision making. But, although we do not feel like having a powerful and convincing "revisionist story" to tell with respect to the initial findings in Rose (2004a), we do have some noteworthy evidence to present. The logic that drives WTO-membership applications and negotiations does, after all, find some empirical support in a comprehensive statistical analysis of overall world 
trade, support that goes beyond individual success stories or a cleverly chosen subset of countries. Based on our analysis, countries who are up for membership may be expected to trade somewhat more with existing member countries, and with more of them, than would otherwise be the case. The magnitude of the effect may not be deemed all that impressive, but it is certainly not negligible either: our preferred estimate lies in the vicinity of a 30-percent boost of bilateral exports from both countries belonging to the WTO. Our findings should also be of some relevance for the broader trade policy debate. It cannot be denied that preaching the virtue of WTO-type multilateralism is made somewhat more difficult if we lack clear empirical evidence of membership effects, either on policies or on trade. Hence, even a modest correction of the earlier scepticism should be welcome. And we do feel that a modest correction is warranted from our results. A corner solutions approach to the gravity equation, which allows for the WTO to have an influence on the amount of bilateral trade as well as on whether a country-pair trades at all, reveals that the low earlier estimates that were based on the amount of trade alone suffer from a downward bias. In addition, the extensive-marginvariation does suggest that membership plays a non-negligible role in creating trading relationships between countries that would otherwise not trade with each other at all. After all, "GATT think" is not entirely unfounded empirically.

We certainly have not had the final word. Future work should focus on methodological refinements, such as for instance a more satisfactory treatment of the "logof-zero-problem" in the log-linear specification of the gravity equation, or a sharper distinction between missing observations and true zeros in the trade data. Related to this, one might also try to run a genuine sample selection story to the effect that the first dollar of trade between any country pair is explained by factors different from those determining the amount of trade in an ongoing trading relationship. It would also be valuable to incorporate some explicit modelling of negotiations related to WTO accession, trying to find out in general terms what makes accession successful (in terms of "GATT think"). A particularly interesting extension of our analysis would be to explore the interaction between regional trading arrangements and WTO membership. Do the trade effects of such arrangements depend on whether or not the participant countries are also long-standing members of the WTO? For lack of space, we have not pursued such questions in this paper, but the technique that we have developed here is readily extended to do so.

In closing, we return to a point that we have argued in our introduction. The 
ultimate cause of the GATT/WTO is not really to promote trade per se, but to free trade from barriers where these are harmful. In this regard, the verdict cannot be found by looking at trade flows; one needs to look at trade policies. And even though there is some evidence that member countries did not systematically conduct more liberal trade policies, the rationale of the GATT/WTO as an institution does not strictly hinge on any such effect either. Bagwell \& Staiger (2003) suggest that the WTO serves a useful purpose in avoiding welfare costs from inefficient non-cooperative policy equilibria. Observing that countries who are members of the WTO do not systematically follow freer (and thus, presumably, less costly) trade policies than non-members, does not invalidate the Bagwell-Staiger case for the WTO: They might still pursue less costly policies than would be the case, if the WTO had not been available as an institution. The same goes, if we find scant evidence that they have more trade than non-members. 


\section{Figures}

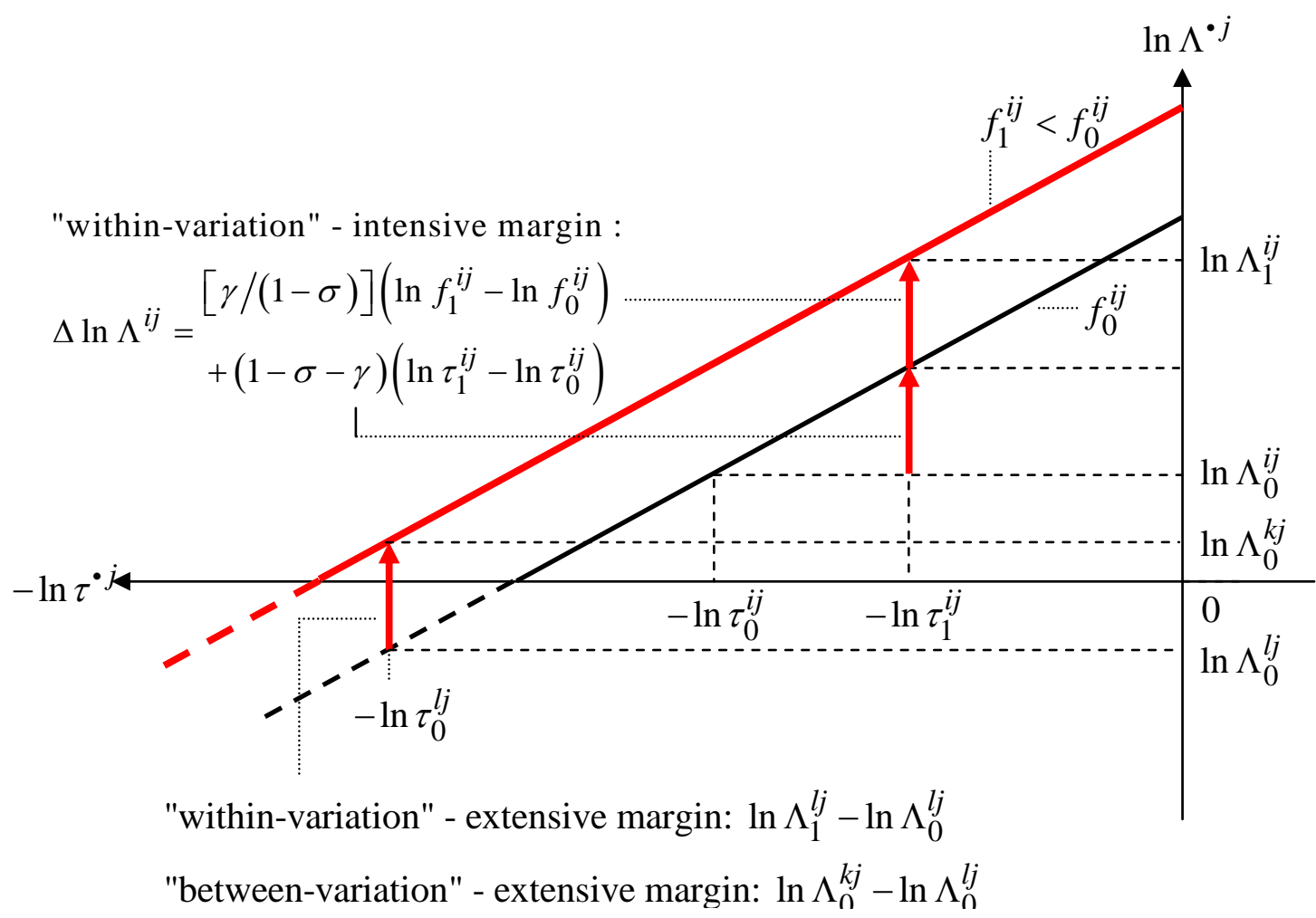

Figure 2.1: The "corner-solutions” model of bilateral exports

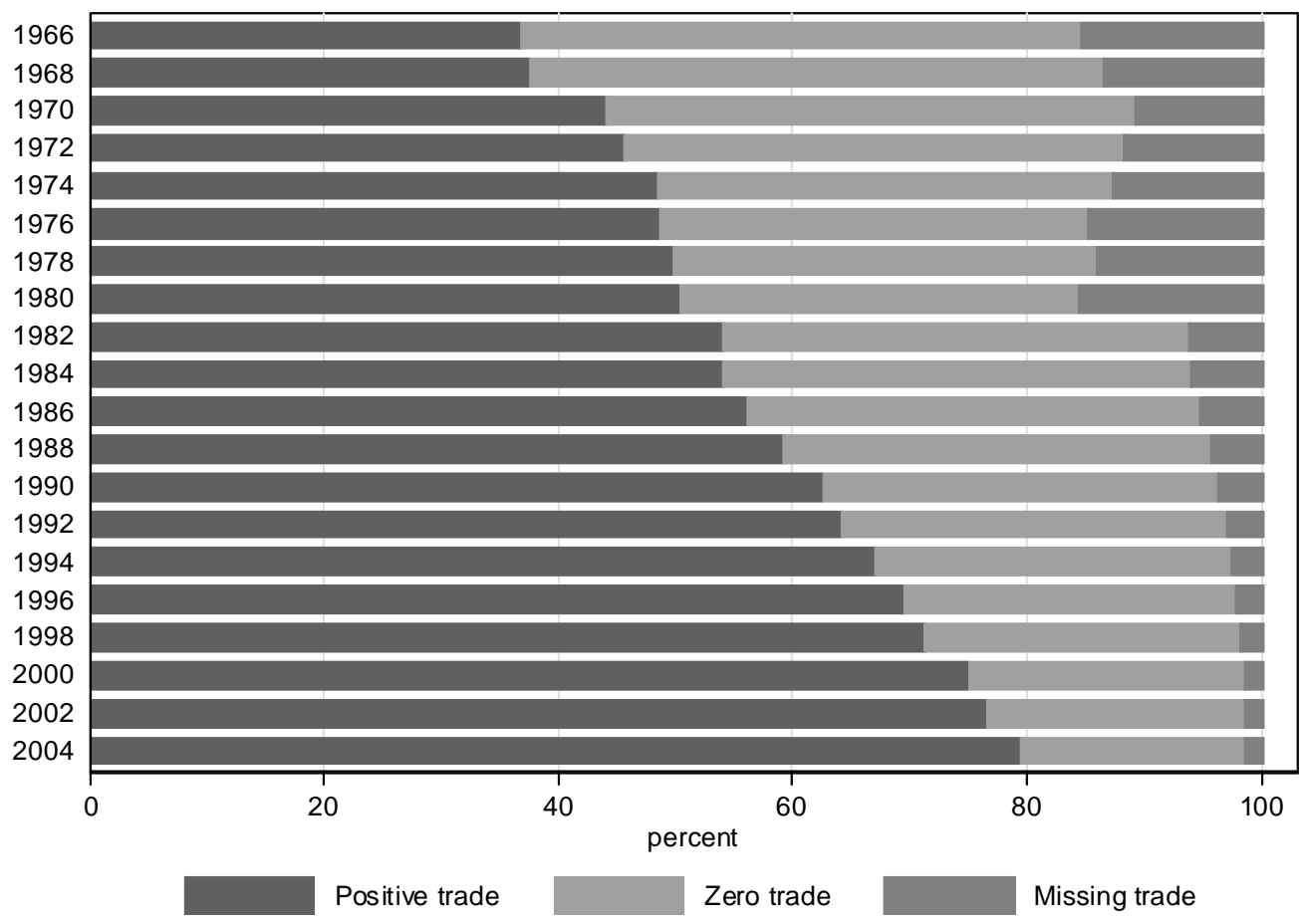

Figure 3.1: Potential export relationships 1966- 2004 


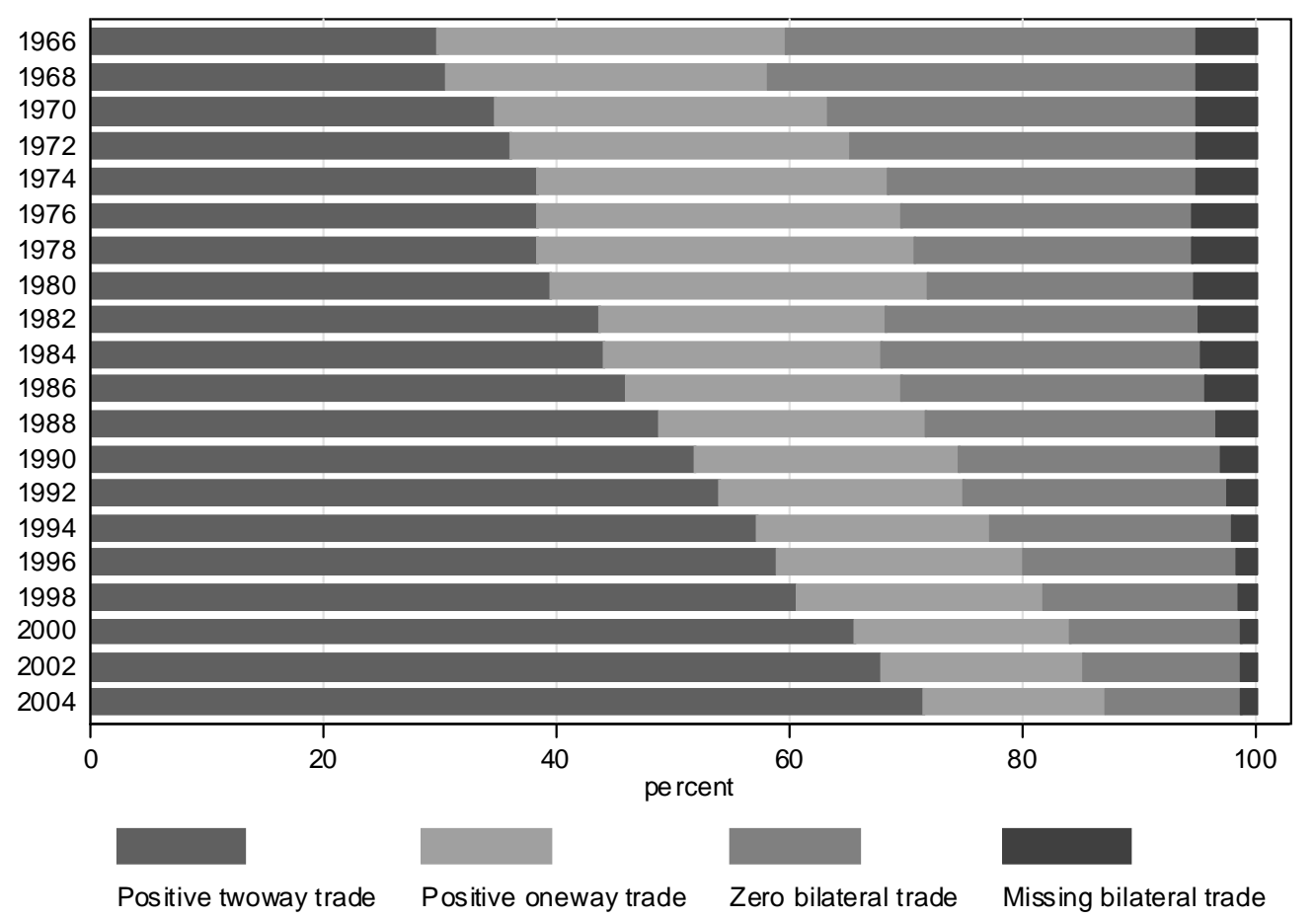

Figure 3.2: $\quad$ Potential bilateral relationships 1966 - 2004

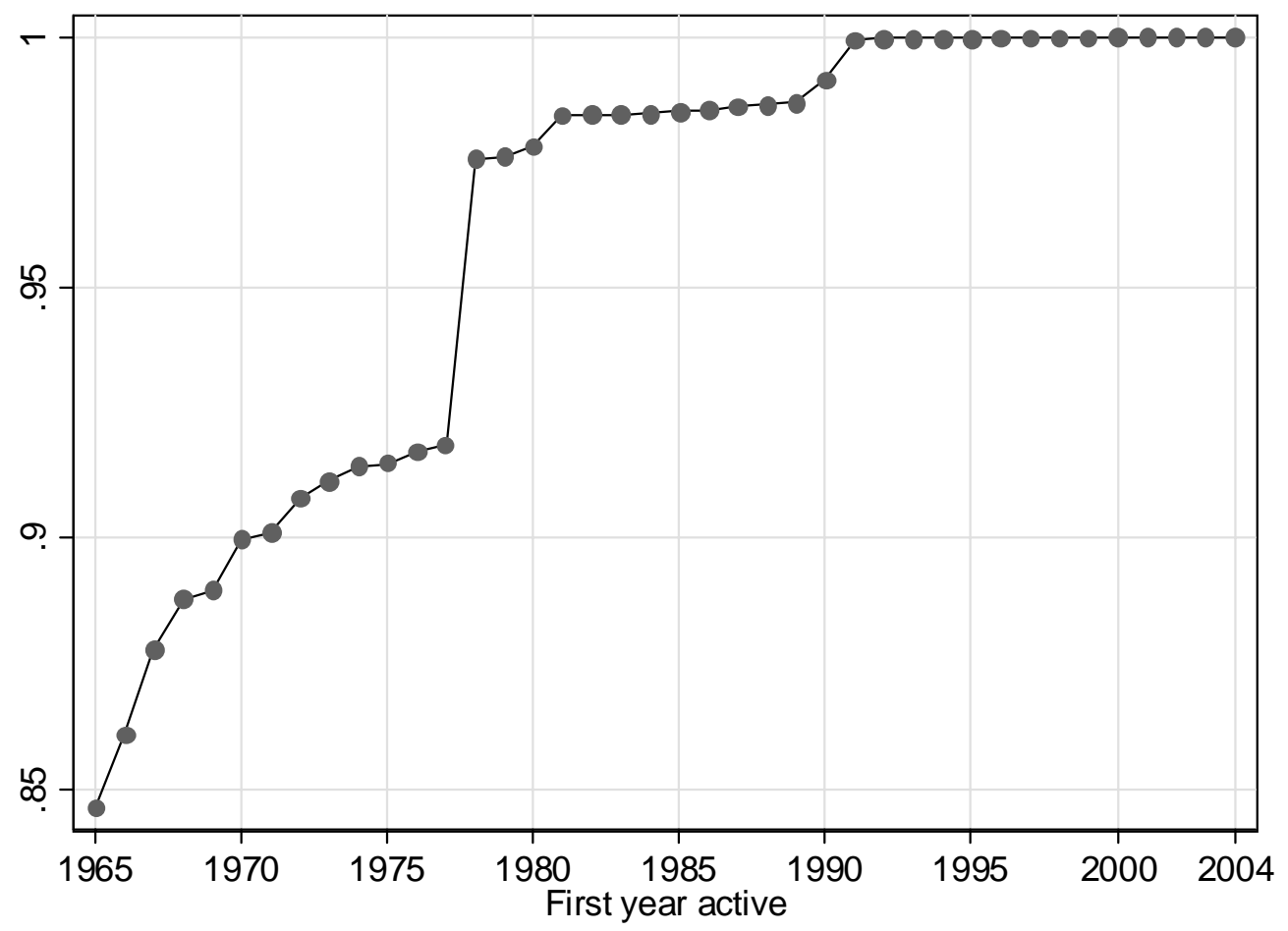

Figure 3.3: Share of "trading-vintages" in 2004 world trade 


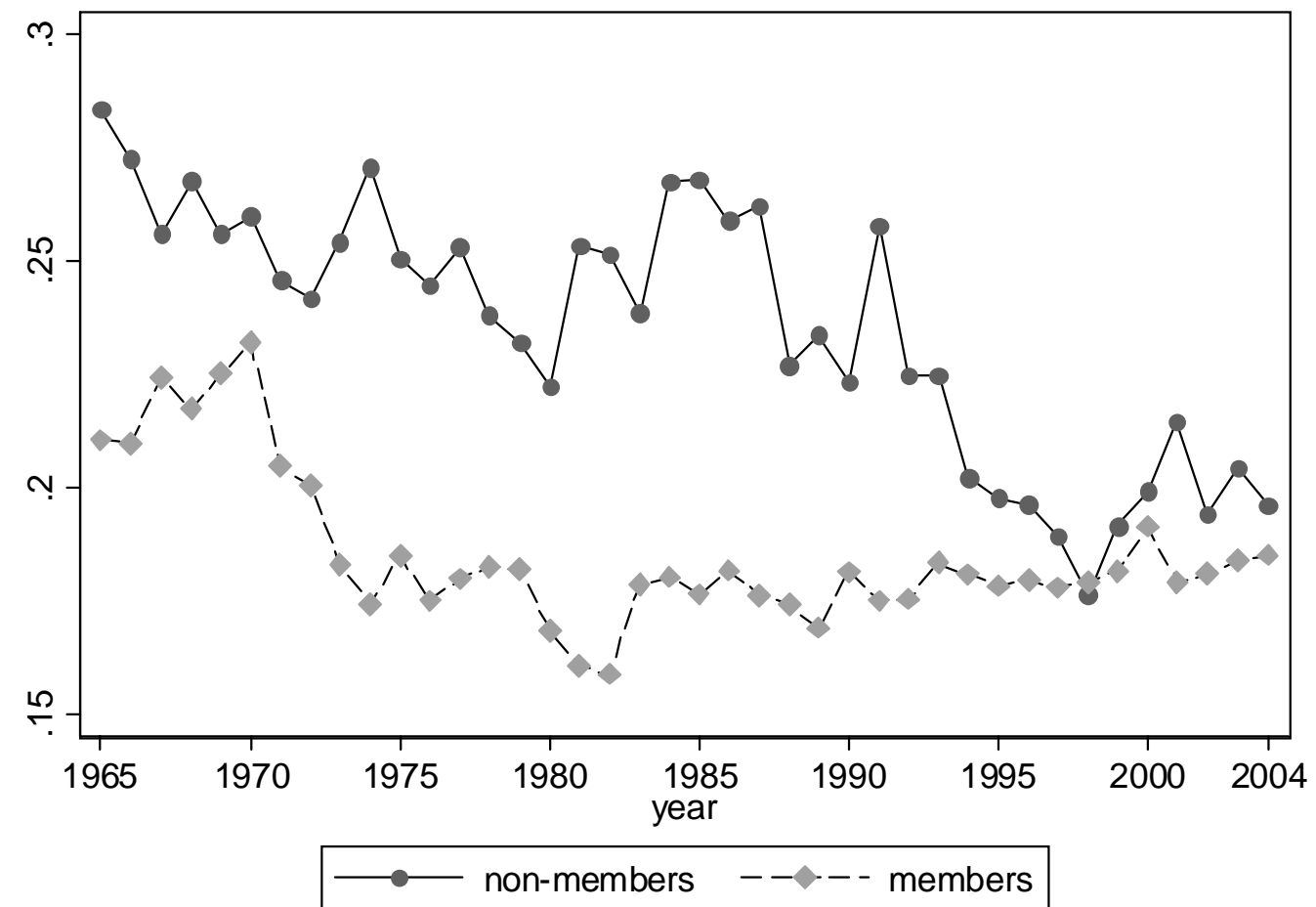

Figure 4.1: Concentration of export destinations -- Herfindahl index

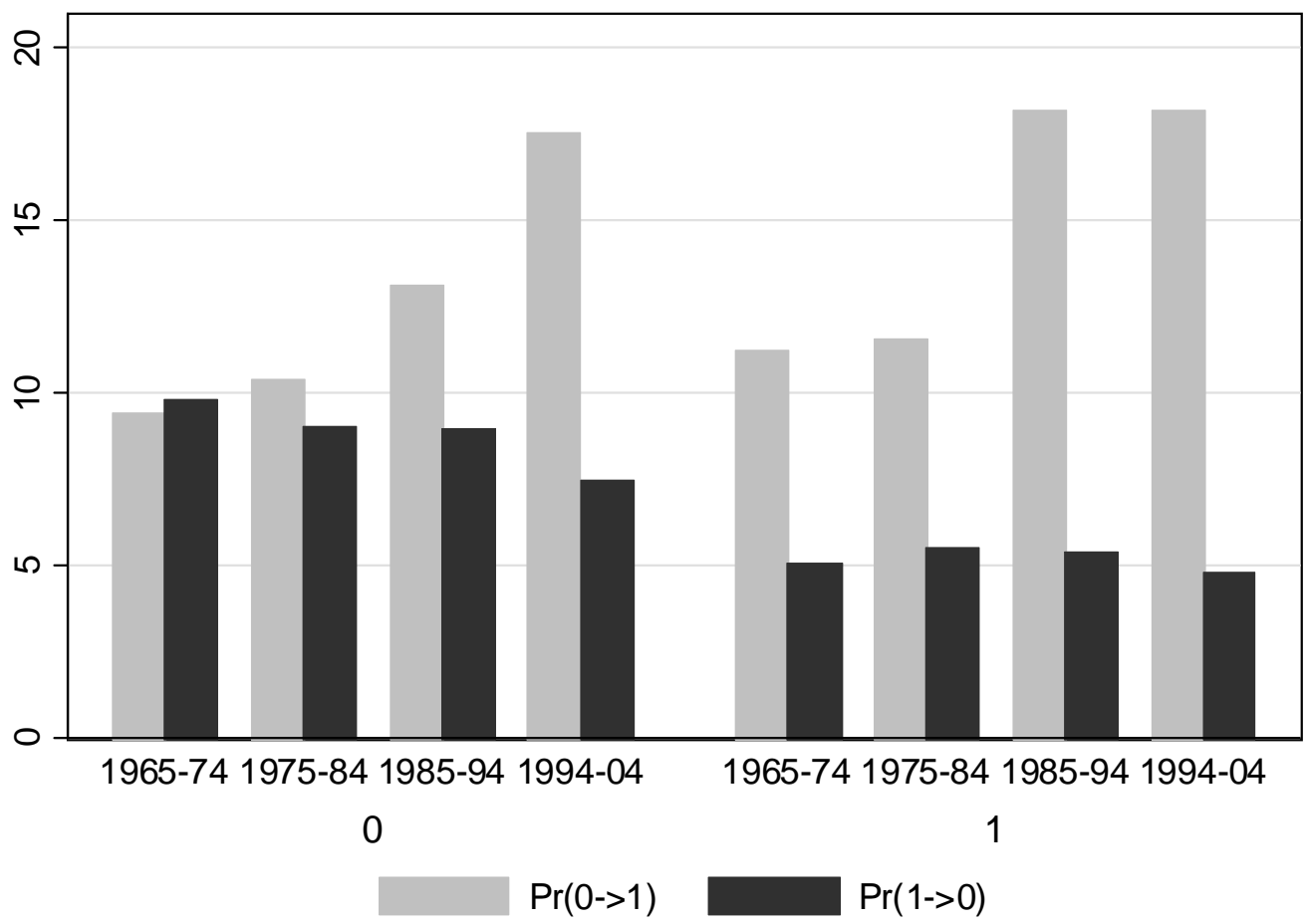

Figure 4.2: Transition probabilities for active/dormant trading relationships 


\section{Tables}

Table 4.1: Existence of trading relationships: Multinomial logit estimates Zero trade (base outcome), oneway trade, twoway trade

\begin{tabular}{lcc}
\hline & Oneway trade & Twoway trade \\
\hline Both in GATT/WTO & -0.081 & 0.153 \\
& $(0.007)$ & $(0.010)$ \\
One in GATT/WTO & -0.083 & 0.192 \\
& $(0.015)$ & $(0.025)$ \\
ln GDP1 & -0.103 & 0.191 \\
& $(0.003)$ & $(0.004)$ \\
ln GDP2 & -0.082 & 0.171 \\
& $(0.003)$ & $(0.004)$ \\
ln DIST & 0.153 & -0.296 \\
& $(0.007)$ & $(0.009)$ \\
Contiguity & -0.115 & 0.193 \\
& $(0.025)$ & $(0.033)$ \\
Common language & -0.064 & 0.126 \\
& $(0.010)$ & $(0.014)$ \\
Observations & & 177,186 \\
Pseudo R2 & & $-120,164$ \\
Log Pseudo-LL & & \\
\hline
\end{tabular}

Note: Coefficients are marginal effects evaluated at sample means for dummy variables ("BOTHIN" and "ONEIN"), the coefficient relates to the discrete change of the dummy from 0 to 1 . Robust standard errors (adjusted for clustering within country pairs) in brackets.

Table 4.2: Number of trading relationships: Poisson regression (panel estimates)

\begin{tabular}{llll}
\hline & Linear (OLS) & Exponential (Poisson) & Negative binomial \\
\hline WTO $^{\mathrm{i}}$ & 4.269 & 0.122 & 0.090 \\
& $(2.152)^{*}$ & $(0.045)^{* *}$ & $(0.045)^{*}$ \\
$\ln \mathrm{GDP}^{\mathrm{i}}$ & 12.336 & 0.142 & 0.133 \\
& $(3.404)^{* *}$ & $(0.067)^{*}$ & $(0.069)$ \\
Constant & -243.422 & -0.389 & -0.317 \\
& $(78.039)^{* *}$ & $(1.213)$ & $(1.247)$ \\
Observations & 3871 & 3871 & 3871 \\
R-squared & 0.56 & & \\
\hline
\end{tabular}

Note: Robust standard errors in parentheses, * significant at 5\%; ** significant at $1 \%$. All regressions include country i and time fixed effects (not shown). 
Table 4.3: Export concentration as a function of WTO membership and other co-vatiates

\begin{tabular}{llll}
\hline WTO & -0.014 & -0.012 & -0.015 \\
$\ln$ GDP & $(0.004)^{* *}$ & $(0.004)^{* *}$ & $(0.004)^{* *}$ \\
& -0.020 & -0.020 & -0.023 \\
$\ln$ GDP & $(0.001)^{* *}$ & $(0.001)^{* *}$ & $(0.001)^{* *}$ \\
& - & - & -0.045 \\
$\ln$ (avg. DIST) & - & - & $(0.012)^{* *}$ \\
$\ln$ (WTO*size) & - & - & 0.034 \\
& - & - & $(0.007)^{* *}$ \\
Observations & - & - & 0.000 \\
Adjusted R-squared & - & - & $(0.000)$ \\
\hline
\end{tabular}

Note: Robust standard errors in parentheses, * significant at 5\%; ** significant at $1 \%$. Specification (2) contains time fixed effects. All specifications contain a constant (not shown). 
Table 5.1: Cross sectional estimation of the gravity equation

Loglinear specification, dependent variable: $\ln (\mathrm{Xij}+1)$

All estimations include exporter- and importer-country fixed effects

\begin{tabular}{|c|c|c|c|c|c|}
\hline & 1965 & 1975 & 1985 & 1995 & 2004 \\
\hline & \multicolumn{5}{|c|}{ INTENSIVE MARGIN (OLS) } \\
\hline BOTHIN $^{\mathrm{ij}}$ & $\begin{array}{l}0.604 \\
(0.695)\end{array}$ & $\begin{array}{l}-3.655 \\
(0.974)^{* *}\end{array}$ & $\begin{array}{l}-0.673 \\
(0.672)\end{array}$ & $\begin{array}{l}-1.194 \\
(0.705)\end{array}$ & $\begin{array}{l}-0.409 \\
(0.421)\end{array}$ \\
\hline ONEIN $^{\mathrm{ij}}$ & $\begin{array}{l}0.499 \\
(0.700)\end{array}$ & $\begin{array}{l}-3.570 \\
(0.990)^{* *}\end{array}$ & $\begin{array}{l}-0.605 \\
(0.679)\end{array}$ & $\begin{array}{l}-1.755 \\
(0.725)^{*}\end{array}$ & $\begin{array}{l}-0.655 \\
(0.481)\end{array}$ \\
\hline $\operatorname{Ln~DIST}^{\mathrm{ij}}$ & $\begin{array}{l}-0.751 \\
(0.035)^{* *}\end{array}$ & $\begin{array}{l}-1.017 \\
(0.039)^{* *}\end{array}$ & $\begin{array}{l}-1.140 \\
(0.040)^{* *}\end{array}$ & $\begin{array}{l}-1.394 \\
(0.036)^{* *}\end{array}$ & $\begin{array}{l}-1.583 \\
(0.036)^{* *}\end{array}$ \\
\hline $\mathrm{ADJ}^{\mathrm{ij}}$ & $\begin{array}{l}0.397 \\
(0.117)^{* *}\end{array}$ & $\begin{array}{l}0.772 \\
(0.157)^{* *}\end{array}$ & $\begin{array}{l}0.676 \\
(0.150)^{* *}\end{array}$ & $\begin{array}{l}0.868 \\
(0.157)^{* *}\end{array}$ & $\begin{array}{l}0.872 \\
(0.163)^{* *}\end{array}$ \\
\hline LANG $^{\mathrm{ij}}$ & $\begin{array}{l}0.645 \\
(0.069)^{* *}\end{array}$ & $\begin{array}{l}0.546 \\
(0.081)^{* *}\end{array}$ & $\begin{array}{l}0.547 \\
(0.079)^{* *}\end{array}$ & $\begin{array}{l}0.817 \\
(0.072)^{* *}\end{array}$ & $\begin{array}{l}0.915 \\
(0.072)^{* *}\end{array}$ \\
\hline $\mathrm{N}$ & 3749 & 5126 & 5910 & 7306 & 8404 \\
\hline $\mathrm{R}^{2}$ & 0.72 & 0.70 & 0.70 & 0.76 & 0.72 \\
\hline \multirow[t]{2}{*}{ RMSE } & 1.20 & 1.68 & 1.76 & 1.78 & 2.12 \\
\hline & \multicolumn{5}{|c|}{ EXTENSIVE MARGIN (PROBIT) } \\
\hline BOTHIN $^{\mathrm{ij}}$ & $\begin{array}{l}0.098 \\
(0.166)\end{array}$ & $\begin{array}{l}0.039 \\
(0.101)\end{array}$ & $\begin{array}{l}-0.167 \\
(0.108)\end{array}$ & $\begin{array}{l}0.301 \\
(0.081)^{* *}\end{array}$ & $\begin{array}{l}-0.073 \\
(0.037)\end{array}$ \\
\hline ONEIN $N^{\mathrm{ij}}$ & $\begin{array}{l}0.106 \\
(0.161)\end{array}$ & $\begin{array}{l}0.072 \\
(0.106)\end{array}$ & $\begin{array}{l}-0.128 \\
(0.089)\end{array}$ & $\begin{array}{l}0.282 \\
(0.106)^{* *}\end{array}$ & $\begin{array}{l}-0.040 \\
(0.042)\end{array}$ \\
\hline Ln DIST $^{\mathrm{ij}}$ & $\begin{array}{l}-0.350 \\
(0.015)^{* *}\end{array}$ & $\begin{array}{l}-0.417 \\
(0.016)^{* *}\end{array}$ & $\begin{array}{l}-0.330 \\
(0.013)^{* *}\end{array}$ & $\begin{array}{l}-0.284 \\
(0.012)^{* *}\end{array}$ & $\begin{array}{l}-0.159 \\
(0.009)^{* *}\end{array}$ \\
\hline$A D J^{i j}$ & $\begin{array}{l}0.419 \\
(0.034)^{* *}\end{array}$ & $\begin{array}{l}0.258 \\
(0.037)^{* *}\end{array}$ & $\begin{array}{l}0.206 \\
(0.027)^{* *}\end{array}$ & $\begin{array}{l}0.094 \\
(0.030)^{* *}\end{array}$ & $\begin{array}{l}0.083 \\
(0.015)^{* *}\end{array}$ \\
\hline LANG $^{\mathrm{ij}}$ & $\begin{array}{l}0.163 \\
(0.025)^{* *}\end{array}$ & $\begin{array}{l}0.210 \\
(0.020)^{* *}\end{array}$ & $\begin{array}{l}0.165 \\
(0.017)^{* *}\end{array}$ & $\begin{array}{l}0.151 \\
(0.012)^{* *}\end{array}$ & $\begin{array}{l}0.078 \\
(0.009)^{* *}\end{array}$ \\
\hline $\mathrm{N}$ & 8300 & 8040 & 9381 & 8650 & 7366 \\
\hline $\mathrm{R}^{2}$ & 0.58 & 0.53 & 0.54 & 0.51 & 0.44 \\
\hline \multirow[t]{2}{*}{ Pseudo LL } & -2389.04 & -2620.71 & -2971.84 & -2765.88 & -2416.11 \\
\hline & \multicolumn{5}{|c|}{ CORNER SOLUTION (TOBIT) } \\
\hline BOTHIN ${ }^{\mathrm{ij}}$ & $\begin{array}{l}- \\
-\end{array}$ & $\begin{array}{l}0.173 \\
(1.512)\end{array}$ & $\begin{array}{l}-2.271 \\
(1.419)\end{array}$ & $\begin{array}{l}4.090 \\
(0.994)^{* *}\end{array}$ & $\begin{array}{l}-1.847 \\
(0.736)^{*}\end{array}$ \\
\hline ONEIN $^{\mathrm{ij}}$ & $\begin{array}{l}- \\
-\end{array}$ & $\begin{array}{l}2.040 \\
(1.540)\end{array}$ & $\begin{array}{l}-0.487 \\
(1.444)\end{array}$ & $\begin{array}{l}3.459 \\
(1.042)^{* *}\end{array}$ & $\begin{array}{l}-1.507 \\
(0.861)\end{array}$ \\
\hline Ln DIST $^{\mathrm{ij}}$ & - & $\begin{array}{l}-4.034 \\
(0.141)^{* *}\end{array}$ & $\begin{array}{l}-3.587 \\
(0.132)^{* *}\end{array}$ & $\begin{array}{l}-3.106 \\
(0.103)^{* *}\end{array}$ & $\begin{array}{l}-2.355 \\
(0.084)^{* *}\end{array}$ \\
\hline$A D J^{i j}$ & $\begin{array}{l}- \\
-\end{array}$ & $\begin{array}{l}1.659 \\
(0.529)^{* *}\end{array}$ & $\begin{array}{l}2.171 \\
(0.496)^{* *}\end{array}$ & $\begin{array}{l}1.264 \\
(0.393)^{* *}\end{array}$ & $\begin{array}{l}1.524 \\
(0.324)^{* *}\end{array}$ \\
\hline LANG $^{i j}$ & - & $\begin{array}{l}3.844 \\
(0.262)^{* *}\end{array}$ & $\begin{array}{l}3.459 \\
(0.251)^{* *}\end{array}$ & $\begin{array}{l}3.223 \\
(0.192)^{* *}\end{array}$ & $\begin{array}{l}2.304 \\
(0.156)^{* *}\end{array}$ \\
\hline $\begin{array}{l}\mathrm{N} \\
\text { Pseudo LL }\end{array}$ & - & $\begin{array}{l}9193 \\
-19596.58\end{array}$ & $\begin{array}{l}10097 \\
-22430.63\end{array}$ & $\begin{array}{l}10452 \\
-25489.26\end{array}$ & $\begin{array}{l}10545 \\
-27381.33\end{array}$ \\
\hline
\end{tabular}

Note: Standard errors in paranthesis, * significant at 5\%, ** significant at $1 \%$. The dependent variable is the natural log of nominal exports from country i to country j. Coefficient estimates for country fixed effects and the constant are not reported for brevity. The number of observations used in the Probit model is lower than in the Tobit case (and sometimes even than in the OLS case), because a large number of outcomes is perfectly predicted by the fixed effects, so that the associated observations are dropped. The linear probability model, that does not suffer from this problem, yields results very similar to the probit case. 
Table 5.2: Panel estimation of the gravity equation

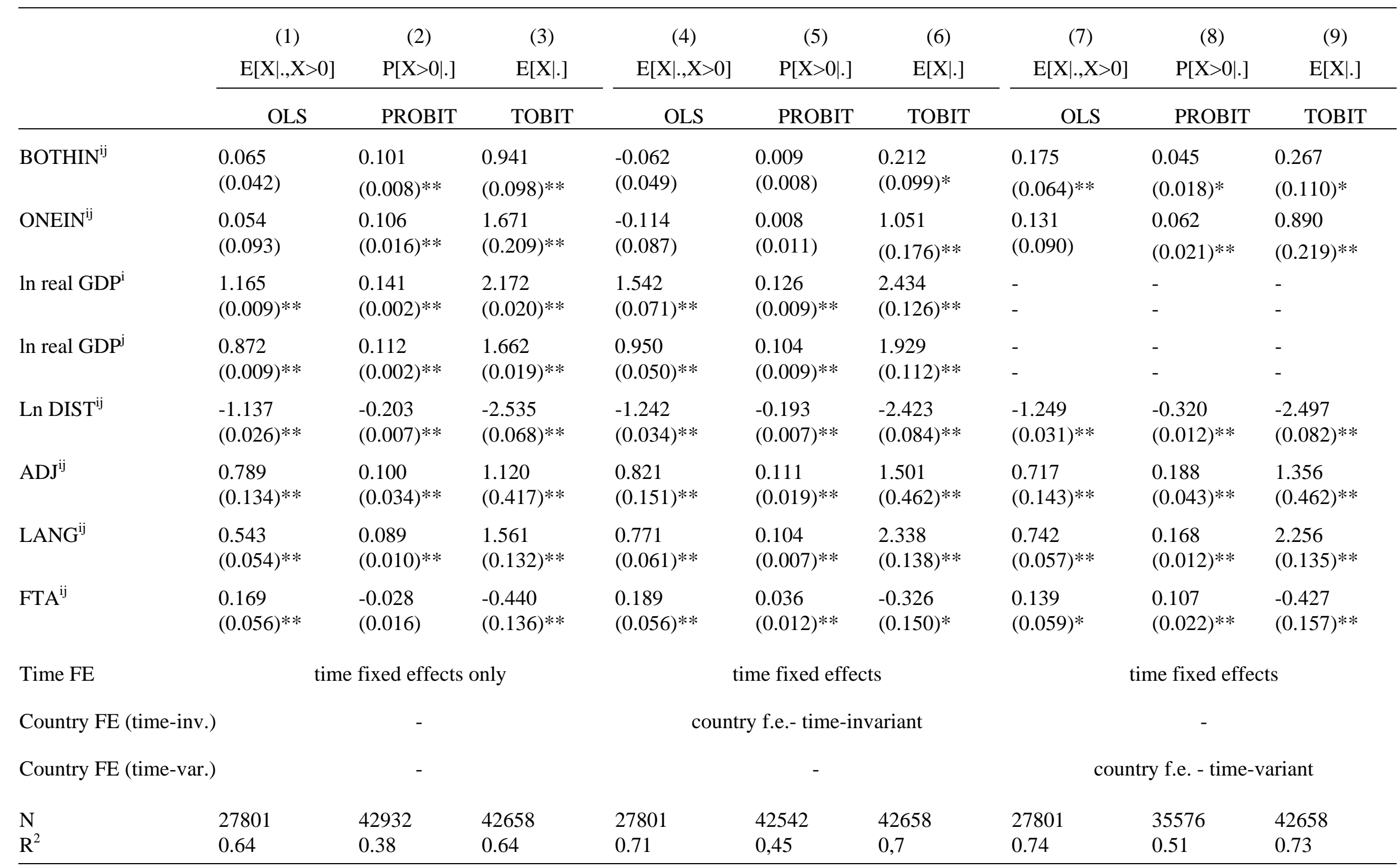

Note: Robust standard errors (adjusted for clustering within groups of country pairs) in parentheses; * significant at $5 \%$; ** significant at $1 \%$.

All specifications (except PROBIT) include constants (not shown), and various fixed effects (not shown). 
Mean

Model: OLS (N = 27,801)

\begin{tabular}{|c|c|c|c|c|}
\hline Ln(Exports) & 11,13 & 3,52 & $-60,31$ & 21,50 \\
\hline BOTHINij & 0,66 & 0,47 & 0,00 & 1,00 \\
\hline ONEINij & 0,96 & 0,20 & 0,00 & 1,00 \\
\hline ln real GDPj & 24,50 & 2,10 & 18,61 & 30,01 \\
\hline ln real GDPi & 24,34 & 2,16 & 18,61 & 30,01 \\
\hline Ln DISTij & 8,58 & 0,85 & 4,45 & 9,89 \\
\hline Adjacencyij & 0,04 & 0,19 & 0,00 & 1,00 \\
\hline Common languageij & 0,20 & 0,40 & 0,00 & 1,00 \\
\hline Free trade agreementij & 0,13 & 0,34 & 0,00 & 1,00 \\
\hline \multicolumn{5}{|c|}{ Model: TOBIT/PROBIT $(\mathrm{N}=42,658)$} \\
\hline Relation is active (dummy) & 0,65 & 0,48 & 0,00 & 1 \\
\hline Ln(Exports+1) & 7,26 & 5,99 & 0,00 & 21,50 \\
\hline BOTHINij & 0,58 & 0,49 & 0,00 & 1,00 \\
\hline ONEINij & 0,93 & 0,25 & 0,00 & 1,00 \\
\hline ln real GDPj & 23,81 & 2,15 & 18,61 & 30,01 \\
\hline ln real GDPi & 23,81 & 2,14 & 18,61 & 30,01 \\
\hline Ln DISTij & 8,68 & 0,79 & 4,45 & 9,89 \\
\hline Adjacencyij & 0,03 & 0,16 & 0,00 & 1,00 \\
\hline Common languageij & 0,18 & 0,38 & 0,00 & 1,00 \\
\hline Free trade agreementij & 0,10 & 0,30 & 0,00 & 1,00 \\
\hline
\end{tabular}

Model: TOBIT/PROBIT $(\mathrm{N}=42,658)$

\begin{tabular}{lllll} 
Ln(Exports) & 11,13 & 3,52 & $-60,31$ & 21,50 \\
BOTHINij & 0,66 & 0,47 & 0,00 & 1,00 \\
ONEINij & 0,96 & 0,20 & 0,00 & 1,00 \\
ln real GDPj & 24,50 & 2,10 & 18,61 & 30,01 \\
ln real GDPi & 24,34 & 2,16 & 18,61 & 30,01 \\
Ln DISTij & 8,58 & 0,85 & 4,45 & 9,89 \\
Adjacencyij & 0,04 & 0,19 & 0,00 & 1,00 \\
Common languageij & 0,20 & 0,40 & 0,00 & 1,00 \\
Free trade agreementij & 0,13 & 0,34 & 0,00 & 1,00 \\
Model: TOBIT/PROBIT (N = 42,658) & & & & \\
Relation is active (dummy) & & & & \\
Ln(Exports+1) & 0,65 & 0,48 & 0,00 & 1 \\
BOTHINij & 7,26 & 5,99 & 0,00 & 21,50 \\
ONEINij & 0,58 & 0,49 & 0,00 & 1,00 \\
ln real GDPj & 0,93 & 0,25 & 0,00 & 1,00 \\
ln real GDPi & 23,81 & 2,15 & 18,61 & 30,01 \\
Ln DISTij & 23,81 & 2,14 & 18,61 & 30,01 \\
Adjacencyij & 8,68 & 0,79 & 4,45 & 9,89 \\
Common languageij & 0,03 & 0,16 & 0,00 & 1,00 \\
Free trade agreementij & 0,18 & 0,38 & 0,00 & 1,00 \\
\hline
\end{tabular}




\section{References}

[1] Anderson, James E. and Eric van Wincoop (2003). Gravity with Gravitas: A Solution to the Border Puzzle. American Economic Review 93(1): 170-192.

[2] Bagwell, Kyle and Robert W. Staiger (2003). The Economics of the World Trading System. Cambridge, Mass.: MIT Press.

[3] Baier, Scott L. and Jeffrey H. Bergstrand (2006). Do Free Trade Agreements Actually Increase Members' International Trade? Journal of International Economics, forthcoming.

[4] Baldwin, Richard (1988). Hysteresis in Import Prices: The Beachhead Effect. American Economic Review 78(4): 773-85.

[5] Baltagi, Badi H., Peter Egger and Michael Pfaffermayr (2003). A Generalized Design for Bilateral Trade Flow Models. Economics Letters 80(3): 391-397.

[6] Evenett, Simon J. and Jonathan Gage (2005). Evaluating WTO Accessions: The Effect of WTO Accession on National Trade Flows. Mimeo: University of St. Gallen.

[7] Evenett, Simon J. and Carlos A. Primo Braga (2005). WTO Accession: Lessons from Experience. World Bank Trade Note No. 22.

[8] Feenstra, Robert C. (2004). Advanced International Trade: Theory and Evidence. Princeton: Princeton University Press.

[9] Felbermayr, Gabriel J. and Wilhelm Kohler (2006). Exploring the Intensive and Extensive Margin of World Trade. Review of World Economics 142(4).

[10] Helpman, Elahan (2006). Trade, FDI, and the Organization of Firms. NBER Working Paper No. 12091.

[11] Helpman, Elahan, Marc J. Melitz and Yona Rubinstein (2006). Trading Partners and Trading Volumes. Mimeo: Harvard University.

[12] Krugman, Paul (1991). The Move Toward Free Trade Zones. Economic Review 76(6): 5-25. 
[13] Liu, Xuepeng (2006). GATT/WTO Promotes Trade Strongly: Sample Selection and Model Specification. Mimeo: Kennesaw State University.

[14] Melitz, Marc J. (2003). The Impact of Trade On Intraindustry Reallocation and Aggregate Industry Productivity. Econometrica 71(6): 1695-1725.

[15] Rose, Andrew K. (2004a). Do We Really Know that the WTO Increases Trade? American Economic Review 94(1): 98-114.

[16] Rose, Andrew K. (2004b). Do WTO Members have More Liberal Trade Policy? Journal of International Economics 63(2): 209-235.

[17] Rose, Andrew K. (2005). Which International Institutions Promote International Trade? Review of International Economics 13(4): 682-698.

[18] Rose, Andrew K. (2006). The Effect of Membership in the GATT/WTO on Trade: Where Do We Stand? Forthcoming in The WTO and Economic Welfare (edited by Zdenek Drabek).

[19] Santos Silva, Joao M.C. and Silvana Tenreyro (2006). The Log of Gravity. Review of Economics and Statistics, forthcoming.

[20] Subramanian, Arvind and Shang-Jin Wei (2006). The WTO Promotes Trade, Strongly But Unevenly. Journal of International Economics, forthcoming.

[21] Tomz, Michael, Judith Goldstein and Douglas Rivers (2005). Membership Has Its Privileges: The Impact of GATT on International Trade. Mimeo: Stanford University.

[22] Wooldridge, Jeffrey M. (2002). Econometric Analysis of Cross Section and Panel Data. Cambridge, Mass.: MIT Press. 


\section{CESifo Working Paper Series}

(for full list see www.cesifo-group.de)

1836 Peter Backé and Cezary Wójcik, Catching-up and Credit Booms in Central and Eastern European EU Member States and Acceding Countries: An Interpretation within the New Neoclassical Synthesis Framework, October 2006

1837 Lars P. Feld, Justina A.V. Fischer and Gebhard Kirchgaessner, The Effect of Direct Democracy on Income Redistribution: Evidence for Switzerland, October 2006

1838 Michael Rauscher, Voluntary Emission Reductions, Social Rewards, and Environmental Policy, November 2006

1839 Vincent Vicard, Trade, Conflicts, and Political Integration: the Regional Interplays, November 2006

1840 Erkki Koskela and Mikko Puhakka, Stability and Dynamics in an Overlapping Generations Economy under Flexible Wage Negotiation and Capital Accumulation, November 2006

1841 Thiess Buettner, Michael Overesch, Ulrich Schreiber and Georg Wamser, Taxation and Capital Structure Choice - Evidence from a Panel of German Multinationals, November 2006

1842 Guglielmo Maria Caporale and Alexandros Kontonikas, The Euro and Inflation Uncertainty in the European Monetary Union, November 2006

1843 Jan K. Brueckner and Ann G. Largey, Social Interaction and Urban Sprawl, November 2006

1844 Eytan Sheshinski, Differentiated Annuities in a Pooling Equilibrium, November 2006

1845 Marc Suhrcke and Dieter Urban, Are Cardiovascular Diseases Bad for Economic Growth?, November 2006

1846 Sam Bucovetsky and Andreas Haufler, Preferential Tax Regimes with Asymmetric Countries, November 2006

1847 Luca Anderlini, Leonardo Felli and Andrew Postlewaite, Should Courts always Enforce what Contracting Parties Write?, November 2006

1848 Katharina Sailer, Searching the eBay Marketplace, November 2006

1849 Paul De Grauwe and Pablo Rovira Kaltwasser, A Behavioral Finance Model of the Exchange Rate with Many Forecasting Rules, November 2006

1850 Doina Maria Radulescu and Michael Stimmelmayr, ACE vs. CBIT: Which is Better for Investment and Welfare?, November 2006 
1851 Guglielmo Maria Caporale and Mario Cerrato, Black Market and Official Exchange Rates: Long-Run Equilibrium and Short-Run Dynamics, November 2006

1852 Luca Anderlini, Leonardo Felli and Andrew Postlewaite, Active Courts and Menu Contracts, November 2006

1853 Andreas Haufler, Alexander Klemm and Guttorm Schjelderup, Economic Integration and Redistributive Taxation: A Simple Model with Ambiguous Results, November 2006

1854 S. Brock Blomberg, Thomas DeLeire and Gregory D. Hess, The (After) Life-Cycle Theory of Religious Contributions, November 2006

1855 Albert Solé-Ollé and Pilar Sorribas-Navarro, The Effects of Partisan Alignment on the Allocation of Intergovernmental Transfers. Differences-in-Differences Estimates for Spain, November 2006

1856 Biswa N. Bhattacharyay, Understanding the Latest Wave and Future Shape of Regional Trade and Cooperation Agreements in Asia, November 2006

1857 Matz Dahlberg, Eva Mörk, Jørn Rattsø and Hanna Ågren, Using a Discontinuous Grant to Identify the Effect of Grants on Local Taxes and Spending, November 2006

1858 Ernesto Crivelli and Klaas Staal, Size and Soft Budget Constraints, November 2006

1859 Jens Brøchner, Jesper Jensen, Patrik Svensson and Peter Birch Sørensen, The Dilemmas of Tax Coordination in the Enlarged European Union, November 2006

1860 Marcel Gérard, Reforming the Taxation of Multijurisdictional Enterprises in Europe, "Coopetition" in a Bottom-up Federation, November 2006

1861 Frank Blasch and Alfons J. Weichenrieder, When Taxation Changes the Course of the Year - Fiscal Year Adjustments and the German Tax Reform 2000/2001, November 2006

1862 Hans Jarle Kind, Tore Nilssen and Lars Sørgard, Competition for Viewers and Advertisers in a TV Oligopoly, November 2006

1863 Bart Cockx, Stéphane Robin and Christian Goebel, Income Support Policies for PartTime Workers: A Stepping-Stone to Regular Jobs? An Application to Young LongTerm Unemployed Women in Belgium, December 2006

1864 Sascha O. Becker and Marc-Andreas Muendler, The Effect of FDI on Job Separation, December 2006

1865 Christos Kotsogiannis and Robert Schwager, Fiscal Equalization and Yardstick Competition, December 2006

1866 Mikael Carlsson, Stefan Eriksson and Nils Gottfries, Testing Theories of Job Creation: Does Supply Create Its Own Demand?, December 2006 
1867 Jacques H. Drèze, Charles Figuières and Jean Hindriks, Voluntary Matching Grants Can Forestall Social Dumping, December 2006

1868 Thomas Eichner and Marco Runkel, Corporate Income Taxation of Multinationals and Unemployment, December 2006

1869 Balázs Égert, Central Bank Interventions, Communication and Interest Rate Policy in Emerging European Economies, December 2006

1870 John Geweke, Joel Horowitz and M. Hashem Pesaran, Econometrics: A Bird's Eye View, December 2006

1871 Hans Jarle Kind, Marko Koethenbuerger and Guttorm Schjelderup, Taxation in TwoSided Markets, December 2006

1872 Hans Gersbach and Bernhard Pachl, Cake Division by Majority Decision, December 2006

1873 Gunther Schnabl, The Evolution of the East Asian Currency Baskets - Still Undisclosed and Changing, December 2006

1874 Horst Raff and Michael J. Ryan, Firm-Specific Characteristics and the Timing of Foreign Direct Investment Projects, December 2006

1875 Jukka Pirttilä and Håkan Selin, How Successful is the Dual Income Tax? Evidence from the Finnish Tax Reform of 1993, December 2006

1876 Agnieszka Stążka, Sources of Real Exchange Rate Fluctuations in Central and Eastern Europe - Temporary or Permanent?, December 2006

1877 Xavier Calsamiglia, Teresa Garcia-Milà and Therese J. McGuire, Why do Differences in the Degree of Fiscal Decentralization Endure?, December 2006

1878 Natacha Gilson, How to be Well Shod to Absorb Shocks? Shock Synchronization and Joining the Euro Zone, December 2006

1879 Scott Alan Carson, Modern Health Standards for Peoples of the Past: Biological Conditions by Race in the American South, 1873 - 1919, December 2006

1880 Peter Huber, Michael Pfaffermayr and Yvonne Wolfmayr, Are there Border Effects in the EU Wage Function?, December 2006

1881 Harry Flam and Håkan Nordström, Euro Effects on the Intensive and Extensive Margins of Trade, December 2006

1882 Panu Poutvaara and Mikael Priks, Hooliganism in the Shadow of the 9/11 Terrorist Attack and the Tsunami: Do Police Reduce Group Violence?, December 2006

1883 Ruud A. de Mooij and Gaëtan Nicodème, Corporate Tax Policy, Entrepreneurship and Incorporation in the EU, December 2006 
1884 Johannes Becker and Clemens Fuest, Corporate Tax Policy and International Mergers and Acquisitions - Is the Tax Exemption System Superior?, January 2007

1885 Momi Dahan and Udi Nisan, The Effect of Benefits Level on Take-up Rates: Evidence from a Natural Experiment, January 2007

1886 José García-Solanes, Francisco I. Sancho-Portero and Fernando Torrejón-Flores, Beyond the Salassa-Samuelson Effect in some New Member States of the European Union, January 2007

1887 Peter Egger, Wolfgang Eggert and Hannes Winner, Saving Taxes Through Foreign Plant Ownership, January 2007

1888 Timothy J. Goodspeed and Andrew Haughwout, On the Optimal Design of Disaster Insurance in a Federation, January 2007

1889 Wim Groot, Henriëtte Maassen van den Brink and Bernard van Praag, The Compensating Income Variation of Social Capital, January 2007

1890 Bas Jacobs, Ruud A. de Mooij and Kees Folmer, Analyzing a Flat Income Tax in the Netherlands, January 2007

1891 Hans Jarle Kind, Guttorm Schjelderup and Frank Stähler, Newspapers and Advertising: The Effects of Ad-Valorem Taxation under Duopoly, January 2007

1892 Erkki Koskela and Rune Stenbacka, Equilibrium Unemployment with Outsourcing under Labour Market Imperfections, January 2007

1893 Maarten Bosker, Steven Brakman, Harry Garretsen, Herman de Jong and Marc Schramm, The Development of Cities in Italy 1300 - 1861, January 2007

1894 Michel Beine, Oscar Bernal, Jean-Yves Gnabo and Christelle Lecourt, Intervention Policy of the BoJ: A Unified Approach, January 2007

1895 Robert S. Chirinko and Daniel J. Wilson, State Investment Tax Incentives: A Zero-Sum Game?, January 2007

1896 Theo S. Eicher and Oliver Roehn, Sources of the German Productivity Demise Tracing the Effects of Industry-Level ICT Investment, January 2007

1897 Helge Berger, Volker Nitsch and Tonny Lybek, Central Bank Boards around the World: Why does Membership Size Differ?, January 2007

1898 Gabriel Felbermayr and Wilhelm Kohler, Does WTO Membership Make a Difference at the Extensive Margin of World Trade?, January 2007 